\title{
Prenatal Deletion of the RNA-Binding Protein HuD Disrupts Postnatal Cortical Circuit Maturation and Behavior
}

\author{
Erik M. DeBoer, ${ }^{1}$ Ricardo Azevedo, ${ }^{1}$ Taylor A. Vega, ${ }^{3}$ Jesse Brodkin, ${ }^{4}$ Wado Akamatsu, ${ }^{5}$ Hideyuki Okano, ${ }^{5}$ \\ George C. Wagner, ${ }^{2 *}$ and Mladen-Roko Rasin ${ }^{1 \star}$ \\ ${ }^{1}$ Department of Neuroscience and Cell Biology, Robert Wood Johnson Medical School and 2Department of Psychology, Rutgers University, Piscataway, New \\ Jersey 08854, ${ }^{3}$ University of California, Berkeley, California 94704, ${ }^{4}$ Behavioral Instruments, Hillsborough, New Jersey 08854, and ${ }^{5}$ Department of \\ Physiology, Keio University, Tokyo 160-8582, Japan
}

The proper functions of cortical circuits are dependent upon both appropriate neuronal subtype specification and their maturation to receive appropriate signaling. These events establish a balanced circuit that is important for learning, memory, emotion, and complex motor behaviors. Recent research points to mRNA metabolism as a key regulator of this development and maturation process. Hu antigen $\mathrm{D}(\mathrm{HuD})$, an RNA-binding protein, has been implicated in the establishment of neuronal identity and neurite outgrowth in vitro. Therefore, we investigated the role of HuD loss of function on neuron specification and dendritogenesis in vivo using a mouse model. We found that loss of $\mathrm{HuD}$ early in development results in a defective early dendritic overgrowth phase and pervasive deficits in neuron specification in the lower neocortical layers and defects in dendritogenesis in the CA3 region of the hippocampus. Subsequent behavioral analysis revealed a deficit in performance of a hippocampus-dependent task: the Morris water maze. Further, $H u D$ knock-out (KO) mice exhibited lower levels of anxiety than their wild-type counterparts and were overall less active. Last, we found that $\mathrm{HuD} \mathrm{KO}$ mice are more susceptible to auditory-induced seizures, often resulting in death. Our findings suggest that HuD is necessary for the establishment of neocortical and hippocampal circuitry and is critical for their function.

\section{Introduction}

Proper functions of the neocortex and hippocampus are required to carry out spatial learning, memory, and complex motor activities (Bystron et al., 2008; Lui et al., 2011; Arnsten, 2013). This functionality is established during an intricate developmental process when excitatory glutamatergic neurons within these regions are born, specified into functionally distinct subpopulations, and organize themselves spatially (Bystron et al., 2008; Kriegstein and Alvarez-Buylla, 2009; DeBoer et al., 2013). Once positioned, neurons create axonal connections with targets either proximal or very distal while also developing complex arbors of dendrites to receive signals from other neuronal afferents. Glutamatergic projection neurons typically exhibit a pyramidal cell body shape, a single apical dendrite that may branch several times before its terminal tuft, as well as an array of basal dendrites, all of

Received Aug. 29, 2013; revised Dec. 23, 2013; accepted Jan. 20, 2014.

Author contributions: E.M.D., G.C.W., and M.-R.R. designed research; E.M.D., R.A., T.A.V., and M.-R.R. performed research; J.B., W.A., H.O., and M.-R.R. contributed unpublished reagents/analytic tools; E.M.D., R.A., T.A.V., G.C.W., and M.-R.R. analyzed data; E.M.D., H.O., G.C.W., and M.-R.R. wrote the paper.

This work was supported by the National Institutes of Health (Grants NS064303 and NS075367 to M.-R.R). E.M.D. was supported by the Rutgers University Bevier Dissertation Fellowship. We thank all current and previous members of the Rasin laboratory; colleagues with whom scientific conversations were instrumental: John Pintar, Renping Zhou, and Li Cai of Rutgers University; and Laura Kus from the Heintz laboratory at The Rockefeller University for her help with DAB and ISH images.

${ }^{*} G$.W. and M.-R.R. contributed equally to this work.

Correspondence should be addressed to Mladen-Roko Rasin, Department of Neuroscience and Cell Biology, Robert Wood Johnson Medical School, Rutgers University, RWJMS Research Tower, 675 Hoes Lane West, R312, Piscataway, NJ 08854. E-mail: roko.rasin@rutgers.edu.

DOI:10.1523/JNEUROSCI.3703-13.2014

Copyright $\odot 2014$ the authors $\quad 0270-6474 / 14 / 343674-13 \$ 15.00 / 0$ which extend spines to receive input. Signaling from axonal afferents and neocortical circuit functions are therefore greatly dependent upon the ability of appropriately positioned neurons to receive input through properly developed dendrites and spines. Disruptions in this process create aberrations in final circuitry and ultimately undermine the function of these regions, resulting in cognitive and motor deficits and seizures (Melzer et al., 2012). Similarly, perturbations in dendrite and spine morphology are hallmarks of many human disorders such as epilepsy and autism spectrum disorders including fragile $\mathrm{X}$ syndrome (Kitaura et al., 2011; Anderson et al., 2012; Clement et al., 2012).

In order for the largely asymmetrical and polar neurons of the neocortex and hippocampus to develop properly, mRNA important for dendritogenesis must be transported and locally translated (Zivraj et al., 2010; Donnelly et al., 2013). Therefore, the maturation of dendrites may be mediated by RNA-binding proteins (RBPs) that bind RNA and mediate transcript metabolism (Akamatsu et al., 2005; Keene, 2007; DeBoer et al., 2013). A large body of work has implicated $\mathrm{Hu}$ antigen $\mathrm{D}(\mathrm{HuD})$, a uniquely brain-expressed RBP, in neurite outgrowth in vitro (Dobashi et al., 1998; Aranda-Abreu et al., 1999; Anderson et al., 2000; Mobarak et al., 2000; Anderson et al., 2001; Abdelmohsen et al., 2010). For example, in cultured PC-12 cells and hippocampal neurons, $\mathrm{HuD}$ silencing resulted in decreased growth of dendrites, the main recipients of axonal afferents (Aranda-Abreu et al., 1999; Akamatsu et al., 2005; Abdelmohsen et al., 2010). Further, genetic mutations in $\mathrm{HuD}$ were associated with movement disorders in humans (Noureddine et al., 2005; Haugarvoll et al., 2007; DeStefano et al., 2008) and $H u D$ depletion in a rodent model resulted in deficiencies 
in rotorod-tested motor performance (Akamatsu et al., 2005). The role of $\mathrm{HuD}$ in the establishment and maturation of dendritic arbors in neocortices in vivo and the impact this has on cortical circuitry, however, has not been investigated.

Therefore, using a mouse loss-of-function model, we evaluated the impact of early $\mathrm{HuD}$ depletion on the specification, arborization, and function of neurons in the adult neocortex and hippocampus. Our findings demonstrate HuD's specific role in the identity and differentiation of a subpopulation of cortical glutamatergic neurons that underlie cognition, spatial memory, and appropriate circuit function.

\section{Materials and Methods}

Subjects. HuD wild-type (WT) and knock-out (KO) mice were bred as littermates from heterozygous parents as described previously (Akamatsu et al., 2005). HuD-GFP reporter mice were purchased from GENSAT (www. gensat.org). We analyzed mice at postnatal day 28 (P28) and P90 using a Golgi method for dendrites; all other analyses were performed at P60-P90. All studies were run blind with respect to subject genotype. Genotyping was performed as described previously (Akamatsu et al., 2005). All procedures were in compliance with Rutgers University Robert Wood Johnson Medical School Institutional Animal Care and Use Committee protocols. A total of 72 mice of either sex were used for analysis.

Immunohistochemistry. Experimental sections were collected and perfused with $150 \mathrm{ml}$ of $4 \%$ PFA, pH 7.4, and postfixed up to $24 \mathrm{~h}$ at $+4^{\circ} \mathrm{C}$. Fixed brains were sectioned coronally using a Leica vibratome at $70 \mu \mathrm{m}$. Immunohistochemical experiments were performed as described previously (Rasin et al., 2007). The following primary antibodies used in dilution: 1:100 rabbit anti-Cdp (M22 catalog \#SC-13024; SCBT), 1:250 mouse anti-Tle4 (E10 catalog \#SC-365406; SCBT), 1:1000 chicken antiGFP (catalog \#GFP-1020; Aves), 1:1000 rabbit anti-glial fibrillary acidic protein (anti-GFAP; catalog \#ab7260; Abcam), 1:100 mouse anti-CC1 (catalog \#OP80; Calbiochem), 1:100 mouse anti-parvalbumin (catalog \#235; Swant), 1:250 mouse anti-NeuN (catalog \#Mab377; Millipore), and 1:250 mouse anti Gad67 (catalog \#MAB5406; Millipore). Secondary antibodies, Cy2, Cy3, and Cy5 were used at 1:250 (Jackson ImmunoResearch). Confocal imaging was performed using an FV1000MPE microscope (Olympus) with $10 \times$ and $60 \times$ Olympus objectives.

Cell specification analysis. Confocal images of immunostained cortical plate of WT and $H u D$ KO $70 \mu \mathrm{m}$ coronal sections were taken. The cortical plate was then equally subdivided into columns of 10 virtual bins from layer II (bin 1) to subplate (bin 10). Total DAPI ${ }^{+}$nuclei were counted, as well as $\mathrm{Cdp}^{+}$or Tle $4^{+}$neurons and $\mathrm{NeuN}^{+}$neurons. Analysis was performed by counting total number of DAPI ${ }^{+}$cells in each column of 10 bins. The proportion of each column's DAPI ${ }^{+}$cells that were $\mathrm{Tle}^{+}, \mathrm{Cdp}^{+}$or $\mathrm{NeuN}^{+}$ was noted for each bin. Three columns were counted per brain and means were compared for each bin between genotypes using a Student's $t$ test. Equal rostral caudal levels were chosen for analysis using the Allen Brain Atlas. $n=$ 4 per genotype and $p<0.05$ was considered significant.

Golgi staining and analysis. HuD WT and KO brains were taken from P28 and P90 mice and processed as per the manufacturer's protocol (rapid Golgi kit; FD Neurotechnologies). Fully processed brains were sectioned at $270 \mu \mathrm{m}$ and coverslipped as per the manufacturer's protocol. $Z$-stack images ( $2 \mu \mathrm{m}$ step) were taken of at least 5 upper and 5 lower layer neocortical projection neurons from the middle of the slice and at least 5 CA3 pyramidal neurons per brain $(n=3$ brains per genotype per age). All images were taken using a Leica DMRE bright-field microscope with Openlab software. Multi-tiff $Z$-stack images of neurons were reconstructed using off-site Neurolucida software and analyzed as described previously (Rasin et al., 2011).

$q R T-P C R$. Cortices were manually dissected from embryonic day 15 (E15), P7, and P90 mice and hippocampi were manually dissected from P7 and P90. Whole RNA was extracted using the RNeasy kit from Qiagen. Resulting RNA was DNAsed using the Ambion Turbo DNase kit. qRTPCR was performed using the Invitrogen one-step qRT-PCR thermocycler. HuD mRNA was quantified using custom TaqMan PN 4331348 probe order AIRR9ZJ and normalized to Gapdh Mm99999915_g1 TaqMan probe using TaqMan RNA-to-CT 1-Step Kit ( $n=2$ brains per age).
Electroporation and cell culture. In utero electroporations were performed using control shRNA and $H u D$ shRNA plasmids (origene sku TG501025) coelectroporated with CAG-RFP or CAG-GFP, respectively, as described previously at E13.5 (Rasin et al., 2007). Electroporated pups were allowed to gestate for $4 \mathrm{~h}$ before they were removed from the dam and the transfected neocortices were manually dissected (see Fig. 6). Dissected cortices were then dissociated and cultured for either 1 or 3 days in vitro (DIV) on laminin and poly-L-ornithine plates using neurobasal medium supplemented with B27, glutamax, sodium pyruvate, and penicillin-streptomycin, as described previously (Sestan et al., 1999). After 1 or 3 DIV, primary cultures were fixed in 4\% PFA, imaged with a confocal microscope, and reconstructed using Neurolucida software (1 DIV Ctrl, $n=5$; 1 DIV HuD shRNA, $n=8$; 3 DIV Ctrl, $n=5$; and 3 DIV $H u D$ shRNA, $n=4)$.

Motor activity. Mice were placed into one of two behavioral spectrometer chambers (Behavioral Instruments). Each chamber consisted of a 40 $\mathrm{cm} \times 40 \mathrm{~cm}$ arena equipped with floor and wall sensors. All vibration, locomotor, and rearing movements were captured by acceleration, weight, and photobeam sensors, respectively. Sensor readings were recorded, analyzed, and compared with a master list of 23 built-in behaviors. Categorization of behavior was achieved using a best-fit procedure such that every second of the session was scored (http://www.behavioralinstruments.com/). Mice were placed in the center of the arena and data were collected for 30 min. Between sessions, the chambers were wiped with $70 \%$ ethanol. Behavioral data collected from the behavioral spectrometers was subjected to a two-way ANOVA (behavioral category repeated) with genotype and behavioral category as the two factors. Post hoc comparisons between genotypes on each behavior were made using a Student-Newman-Keuls procedure; $p<$ 0.05 was considered significant.

Water maze. The water maze consisted of a circular tub $71 \mathrm{~cm}$ in diameter and $29 \mathrm{~cm}$ in height painted white on the interior and filled $3 / 4$ full with water maintained at $23-26^{\circ} \mathrm{C}$ and made opaque with white, nontoxic latex paint. A starting point was determined randomly from one of four equally spaced quadrants. For visible platform testing, an 8.0 -cm-diameter black platform was placed in one quadrant of the maze with the platform $1.5 \mathrm{~cm}$ above the surface. This procedure was repeated 5 times, and a mean of each trial was generated for each genotype $(n=5$ WT and $n=8 \mathrm{KO}$ ). In the hidden platform, an identical platform painted white sat $2 \mathrm{~cm}$ below the surface of the water. Animals received five trials each day and each animal was allowed a maximum of $60 \mathrm{~s}$ to reach the escape platform. A total of four trial days were performed. The position of the hidden platform remained constant throughout the experiment and the room was illuminated and extramaze cues were present. If the animal did not reach the platform in $60 \mathrm{~s}$, a score of 60 was recorded and the animal was gently guided to and placed on the platform. During the intertrial interval of $30 \mathrm{~s}$, all animals rested atop the platform until the next trial began. Mean latency times were collected for each genotype and compared using a oneway ANOVA ( $n=5 \mathrm{WT}$ and $n=8 \mathrm{KO}) . p<0.05$ was considered significant.

Elevated plus maze. The elevated plus maze consisted of 2 long closed arms ( $65 \mathrm{~cm}$ long $\times 8 \mathrm{~cm}$ wide), two short open arms $(30 \mathrm{~cm}$ long $\times 9 \mathrm{~cm}$ wide), and a central square of $5 \mathrm{~cm} \times 5 \mathrm{~cm}$; the maze was $60 \mathrm{~cm}$ above the floor. Each mouse was placed in the center square and observed for 10 min. The number of times the animal crossed into a closed arm or an open arm was recorded as was the total time in each arm. The maze was washed with $70 \%$ alcohol between trials. Mean proportion number of seconds and total proportion of time spent in each arm was collected for each genotype and compared using a Student's $t$ test.

Seizure susceptibility. Seizure susceptibility was assayed in mice individually housed in their home cage using a $30 \mathrm{~s}$ metallic, auditory stimulus of 60 decibels generated 6 inches above the top of the cage. Convulsion was noted if tonic-clonic seizure was provoked. The proportion of animals experiencing seizure was compared using a standard $Z$ test.

\section{Results}

$\mathrm{HuD}$ is expressed in mature hippocampal and cortical glutamatergic neurons

Largely in vitro work has demonstrated $\mathrm{HuD}$ as a marker of differentiated neurons (Szabo et al., 1991; Lee et al., 2003; Darsalia et 
DAPI
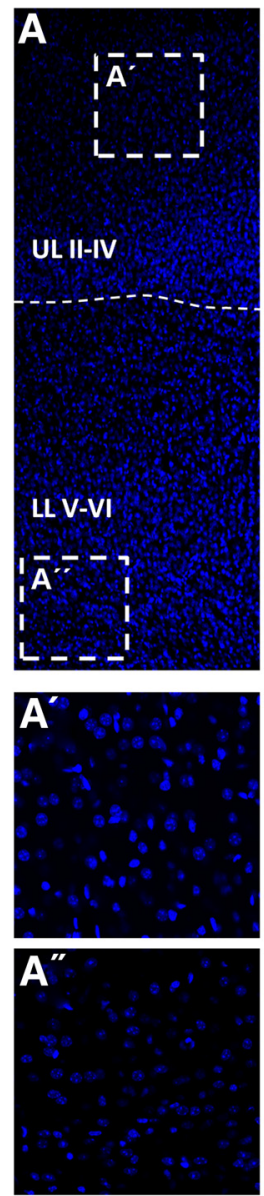

HuD-GFP
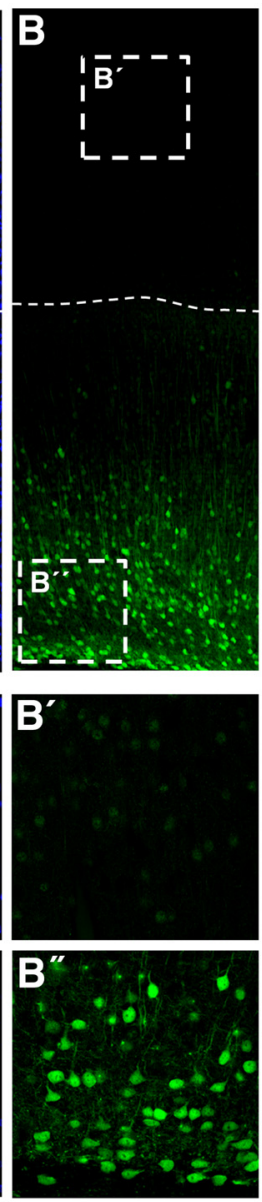

Tle4
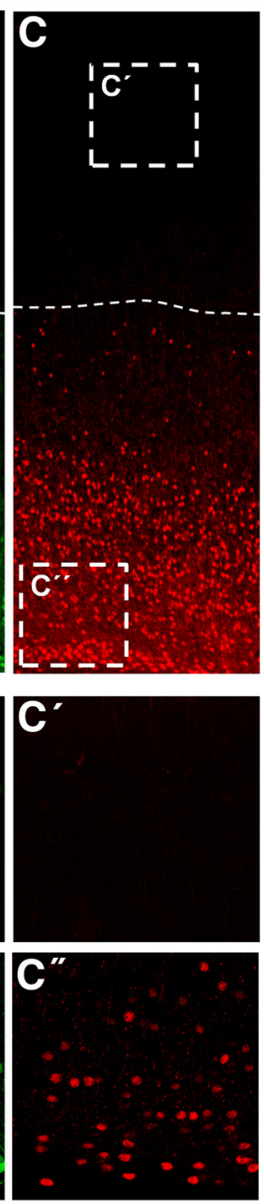

Cdp
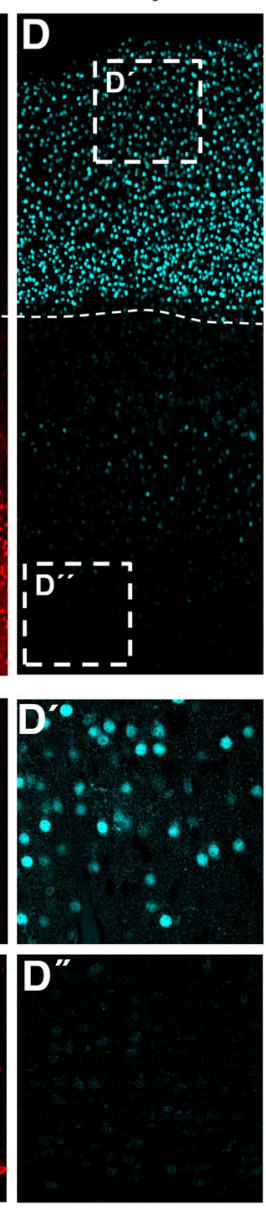

Merge
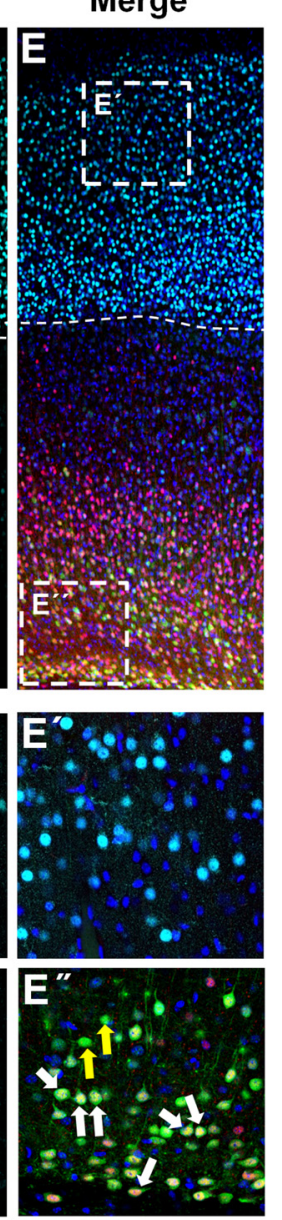

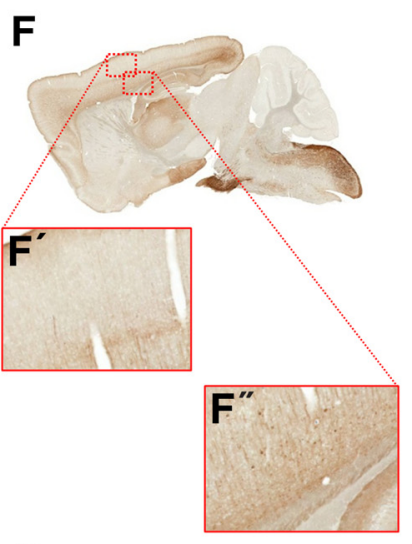

G

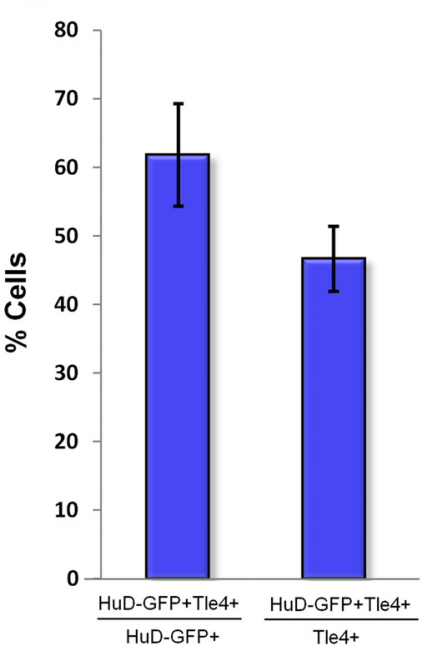

Figure 1. HuD-GFP is expressed in lower- but not upper-layer primary neurons of the mature neocortex. $\boldsymbol{A}-\boldsymbol{E}$, Representative $10 \times$ confocal images of the neocortical wall for DAPI (blue), HuD-GFP (green), Tle4 (red), Cdp (light blue), and merged channels, respectively. Dashed line demarcates upper versus lower neocortical layers. UL, Upper layers; LL, Iower layers. For $\boldsymbol{A}^{\prime}$ - $\boldsymbol{E}^{\prime}$, insets are representative $60 \times$ confocal images of upper neocortical layers; for $\boldsymbol{A}^{\prime \prime}{ }^{\prime}-\boldsymbol{E}^{\prime \prime}$, insets are representative $60 \times$ confocal images of lower neocortical layers. White arrows indicate HuD-GFP/Tle ${ }^{+}$ neurons. Yellow arrows indicate HuD-GFP ${ }^{+} /$Tle4 ${ }^{-}$neurons. $\boldsymbol{F} \boldsymbol{F}^{\prime}$, Representative light microscopy image of HuD-GFP mouse sagittal brain section using anti-GFP-DAB staining (Gong et al., 2003). $\mathbf{G}$, Quantification of the proportion of HuD-GFP ${ }^{+}$neurons colocalized with Tle4 (left) and Tle4 ${ }^{+}$neurons colocalized with HuD-GFP (right).

al., 2007). To address whether HuD is involved in neuronal subtype specification and circuit functions in adults in vivo, we first assessed specificities in $\mathrm{HuD}$ expression in two cortical regions that are rich in diverse neuronal subtypes and have been implicated in learning, memory, and higher cognitive functions: the hippocampus and neocortex. To do this, we obtained an HuDGFP mouse; a transgenic line that expresses Green fluorescent protein (GFP) under the control of the HuD promoter. Through immunohistochemical analysis at P28, we found that GFP is not expressed in the $\mathrm{Cdp}^{+}$upper layer intracortically projecting neocortical neurons (layers II-IV), whereas expression is robust in Tle $4{ }^{+}$subcortically projecting lower layer neurons (Fig. 1A-E). This cortical expression pattern was confirmed through DAB staining for GFP in HuD-GFP transgenic neurons (Fig. $1 F, F^{\prime}, F^{\prime \prime}$; Gong et al., 2003). Upon investigation at $60 \times$ magnification, we found colocalization at $60 \pm 10.5 \%$ of $\mathrm{HuD}^{+}$for Tle $4^{+}$(layers $\mathrm{V}$ and VI) and $46.6 \pm 6.7 \%$ of Tle $4^{+}$neurons were $\mathrm{HuD}^{+}$in subcortically projecting lower layer neurons (Fig. $1 G$ ). These findings suggest that $\mathrm{HuD}$ may be a novel molecular marker for a subpopulation of lower layer neurons in adult neocortices.

Next, we assessed HuD-GFP expression in mature hippocampal regions CA1-3 and the dentate gyrus (Fig. $2 A-D$ ). We found robust expression in all of these hippocampal regions' cell bodies, which is consistent with the location of glutamatergic neurons. Given that we found $\mathrm{HuD}$ expression in $\mathrm{Cdp}^{+}$and Tle ${ }^{+}$neocortical primary neurons, we next assessed whether $\mathrm{HuD}$ is expressed in glutamatergic, excitatory neurons and not GABAergic interneurons (DeFelipe et al., 2013). To this end, we performed immunohistochemistry with antibodies detecting glutamate decarboxylase (Gad67) and the calcium-binding protein parvalbumin. These proteins identify all GABAergic interneurons and subset of interneurons, respectively. We found no colocalizations of either marker of interneurons with $\mathrm{HuD}-\mathrm{GFP}$ in the neocortex or hippocampus (Fig. 2E-L). Further analysis of $\mathrm{HuD}$ expression with CC1, a marker of mature oligodendrocytes, and GFAP, a mature astrocyte marker, also yielded no colocalizations (data not shown). Therefore, these data indicate that $\mathrm{HuD}$ is expressed robustly in a subpopulation of glutamatergic excitatory neurons of lower neocortical layers and the hippocampus.

\section{$\mathrm{HuD}$ is critical for the balanced expression of Tle4 in lower layer neocortical neurons}

The neocortex contains a multitude of neuronal subtypes, and their specification and maintenance are critical to the laminar structure of the neocortex and its function (Arlotta et al., 2005; Guillemot, 2005; Molyneaux et al., 2007; Bithell et al., 2008; Shoe- 


\section{DAPI HuD-GFP}
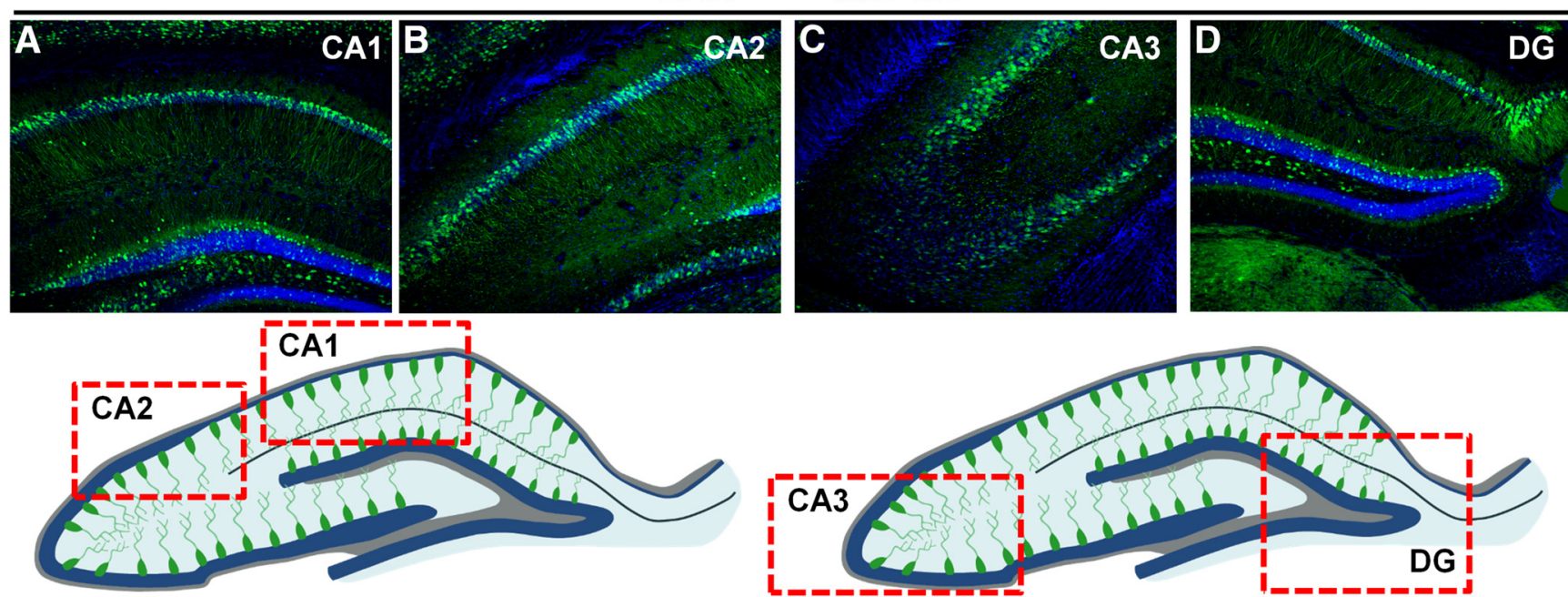

DAPI

HuD-GFP
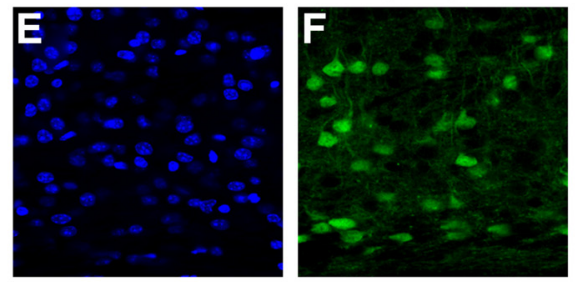

Gad67
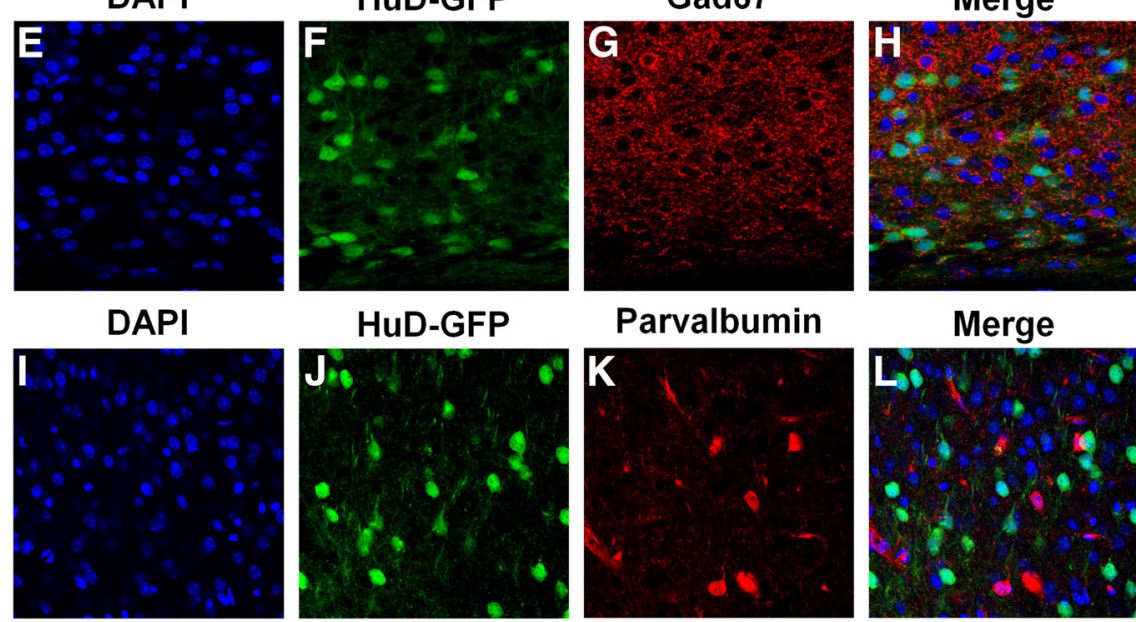

Parvalbumin

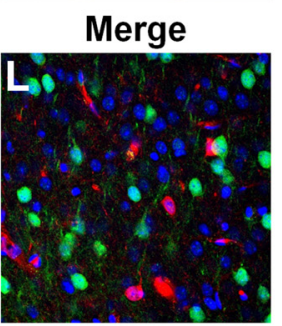

Figure 2. HuD is not expressed in Gad67 or parvalbumin ${ }^{+}$interneurons and is expressed in the CA1-3 and dentate gyrus of the hippocampus. $\boldsymbol{A}-\boldsymbol{D}$, Representative $10 \times$ confocal images of hippocampal subregions CA1, CA2, CA3, and dentate gyrus, respectively. Bottom, Schematic of HuD-GFP expression in the hippocampus. Red boxes denote regions where representative confocal images were captured. $\boldsymbol{E}-\boldsymbol{H}$, Representative $60 \times$ confocal images of cortical of DAPI (blue), HuD-GFP (green), Gad67 (red), and merged channels, respectively. I- $\boldsymbol{L}$, Representative $60 \times$ confocal images of cortical of DAPI (blue), HuD-GFP (green), parvalbumin (red), and merged channels, respectively.

maker and Arlotta, 2010; Kwan et al., 2012; DeBoer et al., 2013). Previous findings indicate that $\mathrm{HuD}$ deletion induces cell death in neural stem cells and cell identity changes in vitro (Akamatsu et al., 2005). HuD KO mice, however, survive to adulthood and are viable. Therefore, we aimed to investigate the role of $H u D$ depletion from the earliest developmental period on the identity of adult neocortical projection neurons. To do this, we bred $\mathrm{HuD}$ $\mathrm{KO}$ mice and performed immunohistochemical analysis of neuronal subtypes identified by Cdp and Tle4 (Fig. $3 A, B$ ) and quantified their distribution in 10 equal bins from layer II (bin 1 ) to the subplate (bin 10). Upon analysis of the proportion of cells $\left(\mathrm{DAPI}^{+}\right)$in each bin that were either Tle $4^{+}$or Cdp ${ }^{+}$, we found a significantly lower proportion of DAPI ${ }^{+}$cells that were Tle $4^{+}$in all but 1 of the bins from bin 6-10, which correspond to lower neocortical layers (mean percentages $0.6,1.6,4.1,4.3$ and 4.5 for WT, respectively, vs $0.4,0.8,3.7$ and 3.1 in $\mathrm{KO}$, respectively; $p=0.043$, $0.005,0.03,0.223$, and 0.01 , respectively; Fig. $3 C$ ). Conversely, we found a modest upregulation of $\mathrm{Cdp}^{+} / \mathrm{DAPI}^{+}$cells in the $\mathrm{HuD}$ KO brains only in bin 5, which is a transition between upper and lower neocortical layers generally without robust expression of either marker (mean percentage $=0.9$ for WT and 0.3 for $\mathrm{KO}$, $p=0.006$; Fig. $3 C$ ). No differences in total DAPI ${ }^{+}$number were observed. When the total proportion of Cdp and Tle ${ }^{+}$cells in each column were considered, we found a slight but insignificant increase in the proportion of $\mathrm{Cdp}^{+}$cells in the KO cortex and a significant downregulation of Tle ${ }^{+}$cells (mean percentage $=$ 45.6 and 32.5 for WT and KO, respectively, $p=0.0004$; Fig. $3 D, E)$. Investigation using a pan-neuronal marker, NeuN, revealed no changes in $\mathrm{NeuN}^{+} / \mathrm{DAPI}^{+}$neurons per neocortical bin or total neocortical $\mathrm{NeuN}^{+} / \mathrm{DAPI}^{+}$neurons (Fig. $3 F, G$, and data not shown). These results suggest that $\mathrm{HuD}$ is involved in the specification and/or maintenance of a subpopulation lower layer neocortical neurons that predominantly project subcortically, which may affect the function of this portion of the neocortical circuit.

Dendritogenesis at P28 is affected in the hippocampus and lower, but not upper, neocortical layers of the $\mathrm{HuD} \mathrm{KO}$ Previous studies have implicated $\mathrm{HuD}$ in neurite outgrowth in vitro (Chung et al., 1997; Dobashi et al., 1998; Aranda-Abreu et al., 1999; Anderson et al., 2000; Mobarak et al., 2000; Anderson et al., 2001; Pascale et al., 2004; Smith et al., 2004; Fukao et al., 2009; Abdelmohsen et al., 2010). To determine whether $H u D$ deletion disrupts cortical dendritogenesis in vivo, we performed a quantitative Golgi analysis on P28 WT and HuD KO neurons of lower 

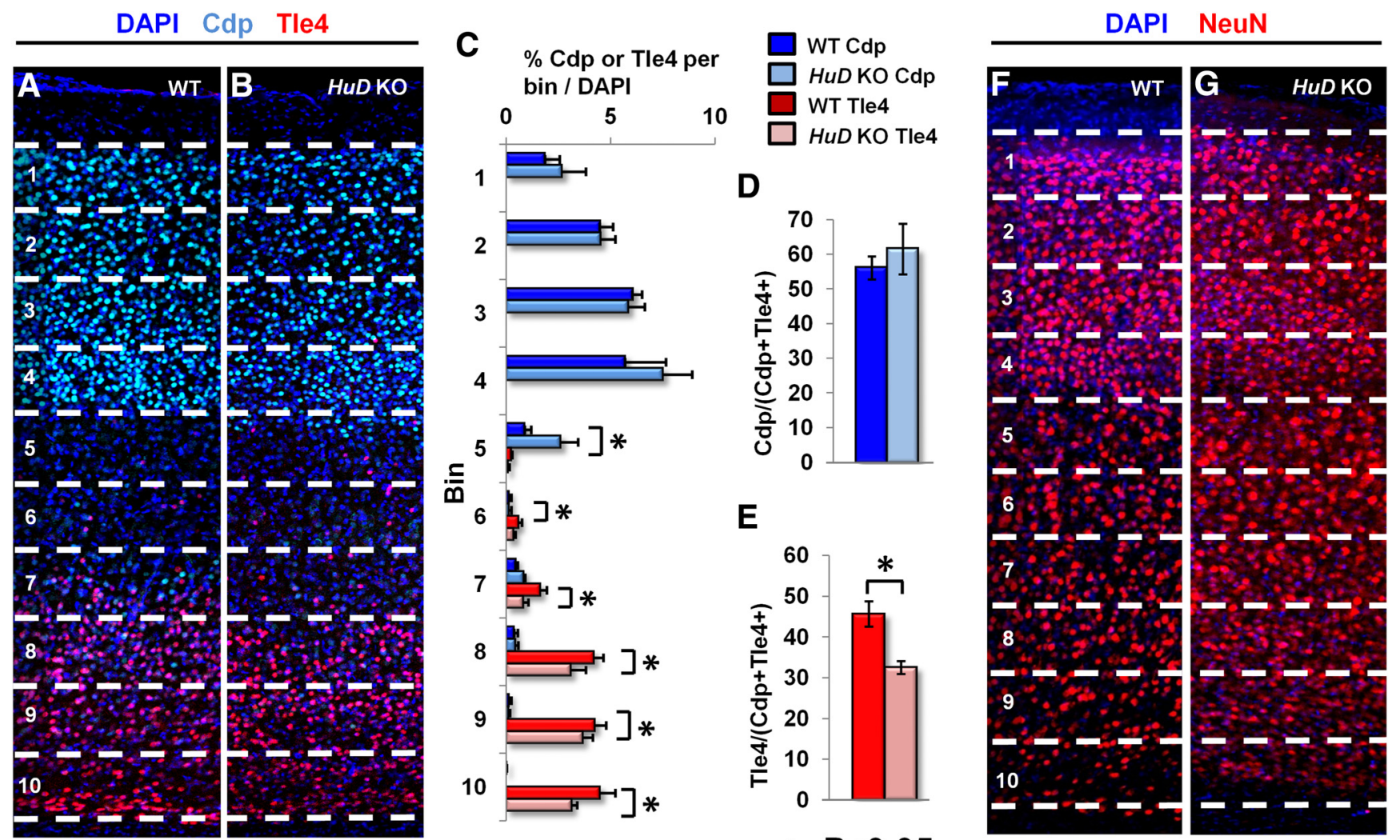

Figure 3. Early loss of HuD function disrupts the specification of lower layer neocortical primary neurons. $A, B$, Representative confocal images of the neocortical wall of adult WT and HuD KO at P90. Numbers and dashed lines denote 10 equal bins for analysis from layer II (bin 1) to the subplate (bin 10). DAPl is shown in dark blue, Tle4 in red, and Cdp in light blue. C, Quantification of the number of $\mathrm{Cdp}^{+}$or Tle4 ${ }^{+}$cells in each bin/the number of DAPI ${ }^{+}$cells in the column. Numbers are reported as the proportion of DAPI ${ }^{+}$cells that are $\mathrm{Cdp}^{+}$or Tle $4^{+}$. Mean bin proportion compared between WT and KO for each bin. D, Quantification of the proportion of $\mathrm{Cdp}^{+}$neurons from total labeled neurons ( $\left(\mathrm{dp}^{+}\right.$Tle4). $E$, Quantification of the proportion of Tle4 ${ }^{+}$neurons from total labeled neurons. $\boldsymbol{F}, \boldsymbol{G}$, Representative confocal images of the cortical plate of adult WT and HuD KO as in $\boldsymbol{A}$ and $\boldsymbol{B}$. DAPl is shown in dark blue and NeuN in red.

and upper neocortical layers and the CA3 region of the hippocampus. Previous investigation has demonstrated that $\mathrm{HuD}$ is involved in circuit formation and function in CA3 (Fig. 4A,D; Tanner et al., 2008; Perrone-Bizzozero et al., 2011). At P28, dendritic arbors are nearly fully formed, but the young animals have had very little exposure to confounding variables that modify dendritic arbors, such as handling, social activity, and sexual maturity (Gibb and Kolb, 2005; Pitchers et al., 2010). Using 3D reconstruction with Neurolucida software in a double-blind fashion, we found decreased dendritic complexity in the lower cortical layers (layers $\mathrm{V}$ and VI) in $H u D$ WT and KOs (Fig. $4 B, C, E, F)$. Within these data, we found that a proportion of neurons show similar branching between WT and KO, whereas a subset of neurons showed significant differences. When we analyzed the entire quantified population as a group, we found that lower layer neurons had fewer basal branch points (mean WT $=$ 9.067 branches, $\mathrm{SE}=2.4$ vs $\mathrm{KO}=6$ branches, $\mathrm{SE}=1.6 ; p=$ 0.03 ), had fewer branch endings (mean $\mathrm{WT}=16$ vs $\mathrm{KO}=12.7$ $p=0.05$ ), and basal dendrites were shorter in total length (mean $\mathrm{WT}=4193 \mu \mathrm{m}, \mathrm{SE}=948 \mathrm{vs} \mathrm{KO}=2478 \mu \mathrm{m}, \mathrm{SE}=211 ; p=$ $0.029)$. Apical dendrites of lower layer neurons were also affected and had fewer branch points (mean WT $=3.3$ branches, $\mathrm{SE}=$ 0.506 vs $\mathrm{KO}=1.8, \mathrm{SE}=0.381 ; p=0.01)$, had fewer dendritic endings (mean $\mathrm{WT}=11.7$ vs $\mathrm{KO}=9.07 p=0.04$ ), and were shorter in total length (mean WT $=3566 \mu \mathrm{m} \mathrm{SE}=403$ vs $\mathrm{KO}=$ $2031 \mu \mathrm{m}, \mathrm{SE}=279 ; p<0.01$; Fig. $4 A, C$ ). The CA3 region of the hippocampus showed decreased differentiation similar to the lower neocortical layers, where CA3 neurons had fewer basal branch points (mean $\mathrm{WT}=9.73, \mathrm{SE}=1.65$ branches vs $\mathrm{KO}=$ 4.6, $\mathrm{SE}=0.58, p=0.007$ ), had fewer dendritic endings (mean $\mathrm{WT}=13.5, \mathrm{SE}=1.70$ vs $\mathrm{KO}=7.8, \mathrm{SE}=0.69, p=0.01)$, and were shorter in total length (mean WT $=4127 \mu \mathrm{m}, \mathrm{SE}=536 \mathrm{vs}$ $\mathrm{KO}=1694, \mathrm{SE}=211, p=0.0005$; Fig. $4 D-F$ ). Apical dendrites of CA3 neurons were also affected and exhibited fewer branch points (mean $\mathrm{WT}=9.8, \mathrm{SE}=1.17 \mathrm{vs} \mathrm{KO}=4.6, \mathrm{SE}=0.72, p=$ 0.0007), had fewer dendritic endings (mean $\mathrm{WT}=10.8, \mathrm{SE}=$ 1.17 vs $\mathrm{KO}=5.67, \mathrm{SE}=0.70, p=0.001)$, and were shorter in total length (mean WT $=4436, \mathrm{SE}=536 \mu \mathrm{m}$ vs $\mathrm{KO}=2048$, $\mathrm{SE}=211, p=0.0002$ ). Interestingly, upper neocortical layers as a group were comparatively unaffected and had similar numbers of basal branch points (mean $\mathrm{WT}=7.3, \mathrm{SE}=1.16$ vs $\mathrm{KO}$ mean $=8.4$, $\mathrm{SE}=1.14, p=0.22)$, basal branch length (mean WT $=3765 \mu \mathrm{m}$, $\mathrm{SE}=376$ vs $\mathrm{KO}$ mean $=3720 \mu \mathrm{m} \mathrm{SE}=518, p=0.047)$, apical branch points (mean $\mathrm{WT}=3.133, \mathrm{SE}=0.68$ mean vs $\mathrm{KO}=4.5$, $\mathrm{SE}=0.85, p=0.082$ ), and apical branch length (mean WT $=3145$ $\mu \mathrm{m}, \mathrm{SE}=403 \mathrm{vs} \mathrm{KO}$ mean $=3500 \mu \mathrm{m}, \mathrm{SE}=451, p=0.26$; data not shown). These data indicate that constitutive loss of $H u D$ early in development has a pervasive effect on the establishment of cortical circuits, particularly on dendritic arborization in a subpopulation of neurons in the adult neocortex and hippocampus.

Dendritic morphology deficits in the hippocampus persist in the adult $\mathrm{HuD} \mathrm{KO}$

We followed our P28 dendritic morphology analysis with an assessment of the P90 adult neocortex and CA3 hippocampus. At this age, we sought to determine whether the deficits that we 
WT

A

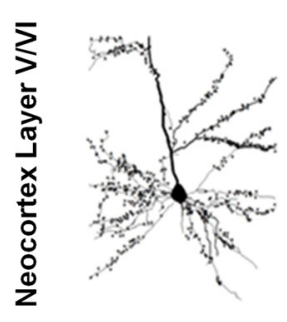

D

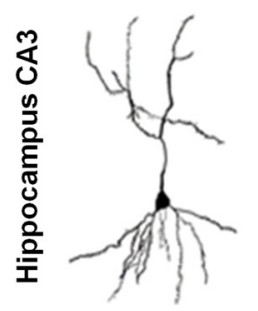

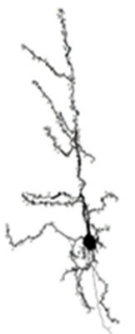

HuD KO

B

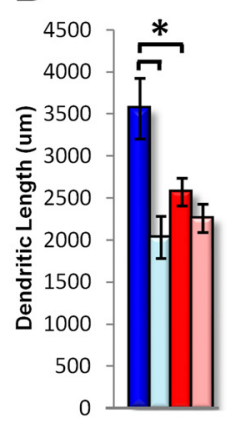

E

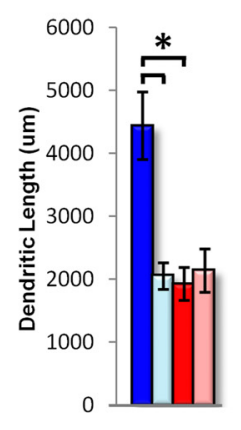

Apical
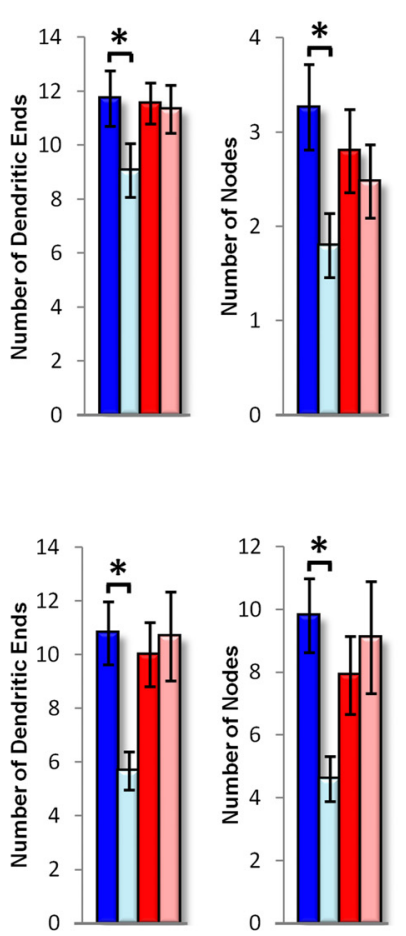

Basal

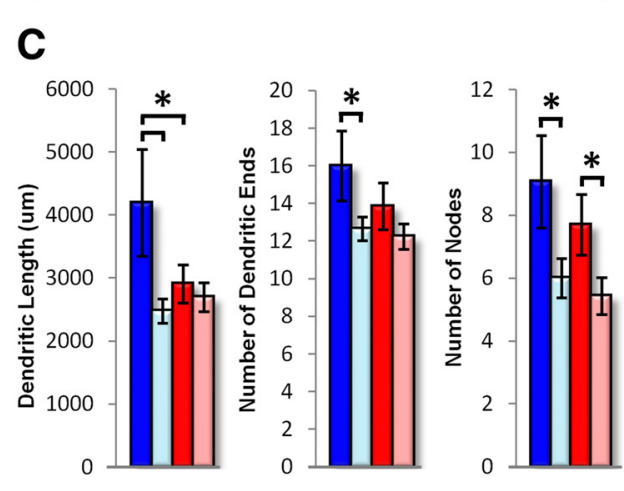

$\mathbf{F}$

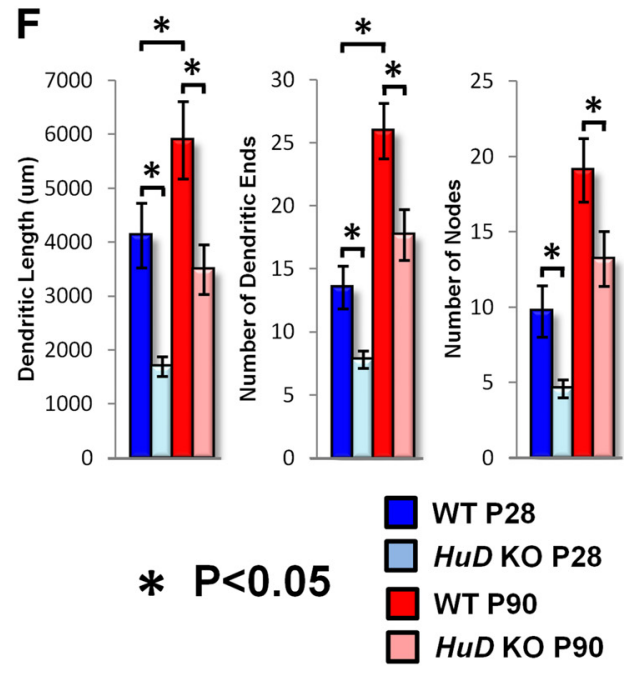

Figure 4. HuD loss of function disrupts dendritogenesis in deep neocortical layers and the CA3 region of the hippocampus. $A, D$, Representative tracings of lower layer neocortical primary neurons (A) and hippocampal CA3 pyramidal neurons (D). B, Quantification of apical dendrite length, dendritic ends, and nodes in lower layer neocortical neurons. C, Quantification of basal dendrite length, dendritic ends, and nodes in lower layer neocortical neurons. $\boldsymbol{E}$, Quantification of apical dendrite length, dendritic ends, and nodes in CA3 pyramidal neurons. $\boldsymbol{F}$, Quantification of basal dendrite length, dendritic ends, and nodes in CA3 pyramidal neurons.

found in developing dendritic arbors persisted in the mature, behaving animal. To this end, we again performed quantitative Golgi on P90 animals and reconstructed neurons in the CA3 hippocampus and lower neocortical layers (Fig. 4A,D). Our findings in the neocortex indicate that overall basal and apical length decreased from P28 to P90 in WT animals (to $69 \%$ and $72 \%$ of P28 length, $p=0.06$ and $p=0.002$, respectively), which is consistent with previous findings of a lifespan of dynamic changes in dendrite length (Metzger, 2010). KO lengths however, did not change discernibly (P90 length $=92 \%$ and $90 \%$ of P28 length of basal and apical dendrites, respectively). Neocortical arborization in lower layers at P90 did not reach significance for the metrics of apical dendritic length (mean $\mathrm{WT}=2572, \mathrm{SE}=166 \mathrm{vs}$ $\mathrm{KO}=2260, \mathrm{SE}=168, p=0.09$ ), dendritic branches (mean $\mathrm{WT}=2.8, \mathrm{SE} 0.4$ vs $\mathrm{KO}=2.4, \mathrm{SE}=0.4, p=0.29$ ), or dendritic endings (mean $\mathrm{WT}=11.6, \mathrm{SE}=0.76$ vs $\mathrm{KO}=11.3, \mathrm{SE}=0.89$, $p=0.4$; Fig. $4 B$ ). Basal branching was persistently deficient in neocortical lower layer neurons (mean $\mathrm{WT}=7.7, \mathrm{SE}=0.97 \mathrm{vs}$ $\mathrm{KO}=5.4, \mathrm{SE}=0.59, p=0.03$ ) and whereas other indices showed some reduction, significance was not reached in basal length (mean $\mathrm{WT}=2906 \mu \mathrm{m}, \mathrm{SE}=300$ vs $\mathrm{KO}=2696 \mu \mathrm{m}, \mathrm{SE}=228$, $p=0.28$ ) or basal branch endings (mean WT $=13.9$, SE 1.23 and $\mathrm{KO}=12.2, \mathrm{SE}=0.67, p=0.1 ; \mathrm{Fig} .4 C$ ). These data suggest that $\mathrm{HuD}$ is required for the expansion/overgrowth of dendrites during early postnatal development in mice.
Analysis of the CA3 hippocampus at P90 showed no significant change in the apical region for branch length (mean WT $=$ $1923, \mathrm{SE}=261$ vs $\mathrm{KO}=2138$, SE 343, $p=0.31$ ), branches (mean $\mathrm{WT}=7.3, \mathrm{SE}=1.2$ vs $\mathrm{KO}=9.1, \mathrm{SE}=1.8, p=0.29)$, or branch endings (mean $\mathrm{WT}=10, \mathrm{SE}=1.18$ and $\mathrm{KO}=10.6, \mathrm{SE} 1.7, p=$ 0.36; Fig. $4 E$ ). However, persistent defects in basal branch length (mean $\mathrm{WT}=5890 \mu \mathrm{m}, \mathrm{SE}=716$ vs $\mathrm{KO}=3431, \mathrm{SE}=457, p=$ 0.004 ), basal branching (mean $\mathrm{WT}=19.1, \mathrm{SE}=2.1$ vs $\mathrm{KO}=$ 13.2 , SE 1.8, $p=0.02$ ), and basal branch endings (mean WT $=26$, $\mathrm{SE}=2.2$ vs $\mathrm{KO}=18, \mathrm{SE}=2, p=0.004$ ) were noted (Fig. $4 F$ ). In sum, these findings demonstrate that $\mathrm{HuD}$ is involved in the development of apical and basal dendrites in lower neocortical layers and the hippocampal CA3 region and that many of these deficits persist in the mature animal, suggesting functional circuit deficits.

\section{$\mathrm{HuD}$ levels decrease from E15 to adult in the neocortex and hippocampus}

To ascertain the relationship between $\mathrm{HuD}$ expression and the selective arborization defects we discovered at P28 and $\mathrm{P} 90$, we next investigated the developmental expression of $\mathrm{HuD}$ across the timeframe of our studies. Therefore, we accessed the GENSAT database for developmental confirmatory images of the HuD-GFP reporter mouse that we characterized here (Fig. 5A-C; Gong et al., 2003). These images show that HuD-GFP DAB signal 
E14.5
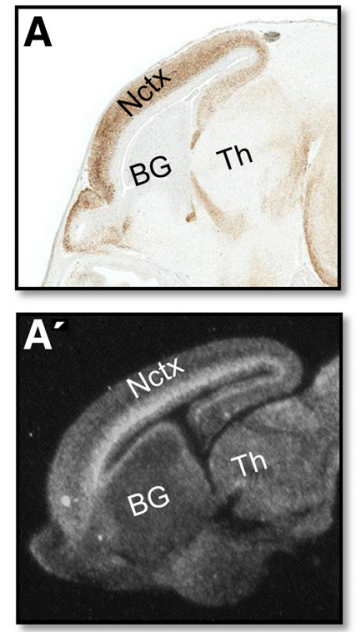

D

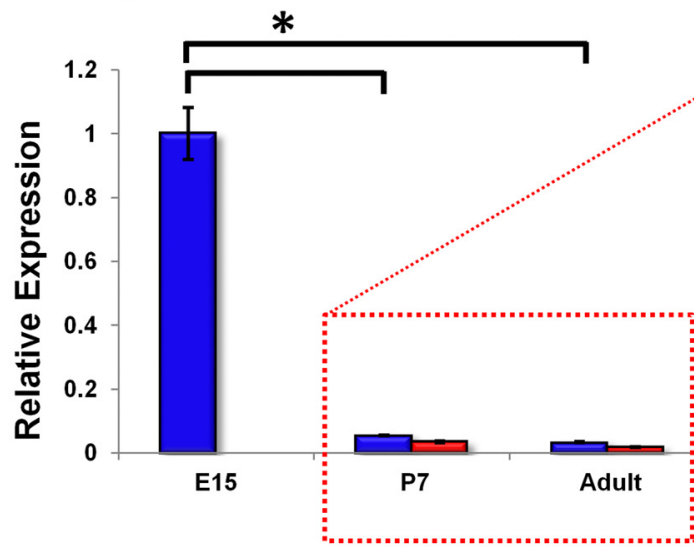

P7
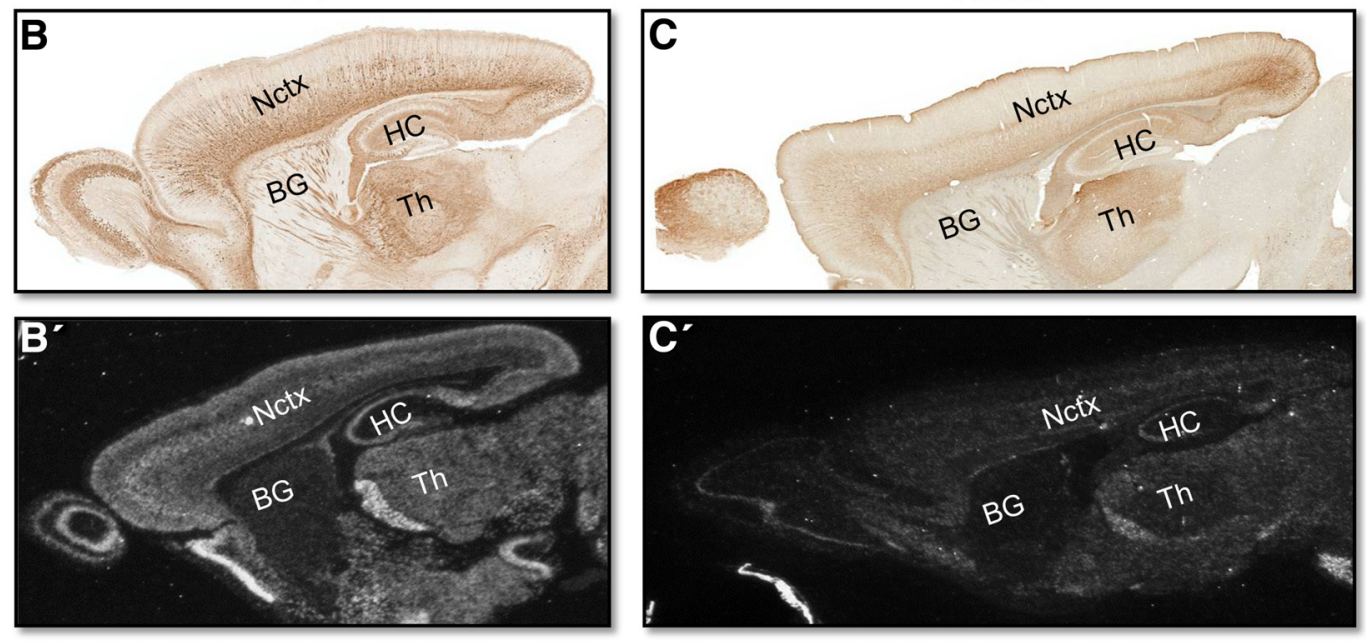

E

Adult
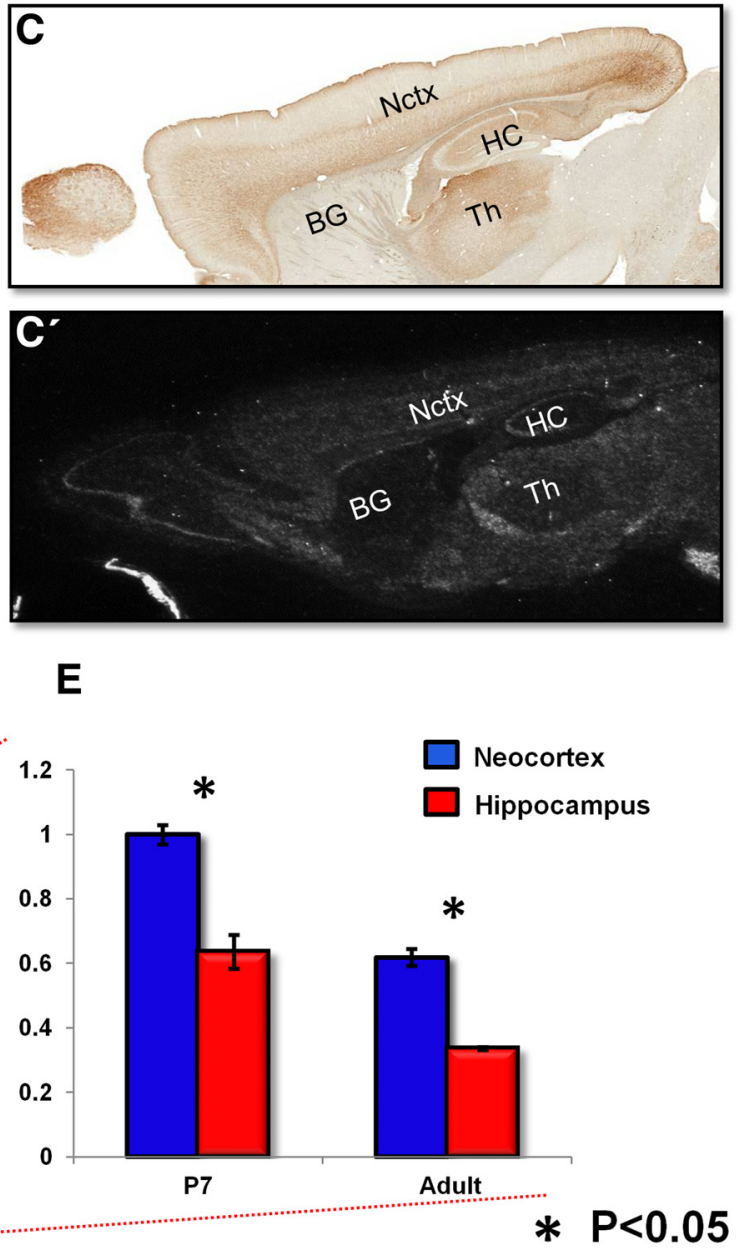

Figure 5. HuD expression decreases from E14.5 until adult and becomes more regionally specific. $\boldsymbol{A}-\boldsymbol{C}$, Representative images of HuD-GFP mouse sagittal brain sections stained with anti GFP DAB. E14.5, P7, and adult, respectively (Gong et al., 2003). $\boldsymbol{A}^{\prime}-\boldsymbol{C}^{\prime}$, Representative images of HuD ISH mouse sagittal brain sections at E14.5, P7, and adult, respectively (Magdaleno et al., 2006). D, $\boldsymbol{E}$, qRT-PCR of developing neocortex at E15, P7, and adult. Hippocampus analysis at P7 and adult. Gapdh was used for normalization. Values were normalized to E15 neocortex in $\boldsymbol{D}$. Values were normalized to P7 neocortex in $\boldsymbol{E}$.

decreases from E15 to $\mathrm{P} 7$ and becomes more regionally restricted to lower layer neurons (Fig. 5A,B). HuD signal decreases again in the adult and is restricted only to lower layers (Fig. 5C). To confirm this expression, we accessed the St. Jude Research Hospital in situ database and searched for $\mathrm{HuD}$ in situ images complementary to the HuD-GFP DAB staining (Magdaleno et al., 2006). $H u D$ mRNA expression closely resembled the HuD-GFP DAB pattern, particularly at the $\mathrm{P} 7$ and adult stages (Fig. $5 A^{\prime}-C^{\prime}$ ). It should be noted that the untagged GFP molecule is free to diffuse into any compartment of the cell, which may explain DAB signal in regions where mRNA is not detected. Subsequently, we confirmed the $H u D$ mRNA expression decrease from E15 to adult quantitatively by performing qRT-PCR for HuD at E15, P7, and adult in hippocampal and neocortical tissue (Fig. 5D,E). Our results demonstrate a significant decrease in $H u D$ mRNA from E15 to P7 in both hippocampus and neocortex (normalized to E15 neocortex, $\mathrm{SE}=0.08$; mean fold change to $\mathrm{P} 7$ neocortex $=$ $0.054, \mathrm{SE}=0.001$; mean fold change to $\mathrm{P} 7$ hippocampus $=0.034$, $\mathrm{SE}=0.003, p<0.01$ for all measures). Closer examination of the relationship between P7 HuD expression and adult reveals a subsequent decrease in $H u D$ expression from P7 to adult in either cortical region (normalized to $\mathrm{P} 7$ neocortex $\mathrm{HuD}$ expression $(\mathrm{SE}=0.03$-fold, $\mathrm{P} 7$ hippocampus mean fold change $=0.64, \mathrm{SE}=$
0.05; mean fold change to adult neocortex $=0.62$ fold, $\mathrm{SE}=0.05$; and mean fold change to adult hippocampus $=0.34, \mathrm{SE}=0.004$, $p<0.01$ for all measures; Fig. 5E).

\section{$H u D$ depletion disrupts dendritic outgrowth in cultured neocortical neurons}

We next investigated how early $\mathrm{HuD}$ is required in dendritic arborization. In Figure $5 A$, we show that $\mathrm{HuD}$ is highly expressed in the developing neocortical plate during neocorticogenesis, which is in agreement with previous studies (Okano and Darnell, 1997; Gong et al., 2003; Magdaleno et al., 2006). Therefore, we performed in utero electroporation of Ctrl shRNA/RFP or an efficient HuD shRNA/GFP plasmid at E13, when lower layer neocortical neurons are born (Fig. 6A-B'; Rasin et al., 2007; DeBoer and Rasin, 2013). We then dissociated the transfected neocortices and cultured them for 1 and $3 \mathrm{~d}$ before fixing and reconstructing the resulting transfected neurons (Fig. 6C,D). We found no significant difference in the number of dendrites per cell or the length of dendrites at $1 \mathrm{DIV}$ (mean dendrites Ctrl $=3.4 \pm 0.81$ vs $H u D$ shRNA $=2 \pm 0.65$, mean dendritic length Ctrl $=11.1 \pm$ 2.31 vs $H u D$ shRNA $=9.11 \pm 2.13 \mu \mathrm{m}$, Fig. $6 E, G, I, K)$. Although there was no significant change in dendrite number at 3 DIV, we noted a significant decrease in dendritic length com- 

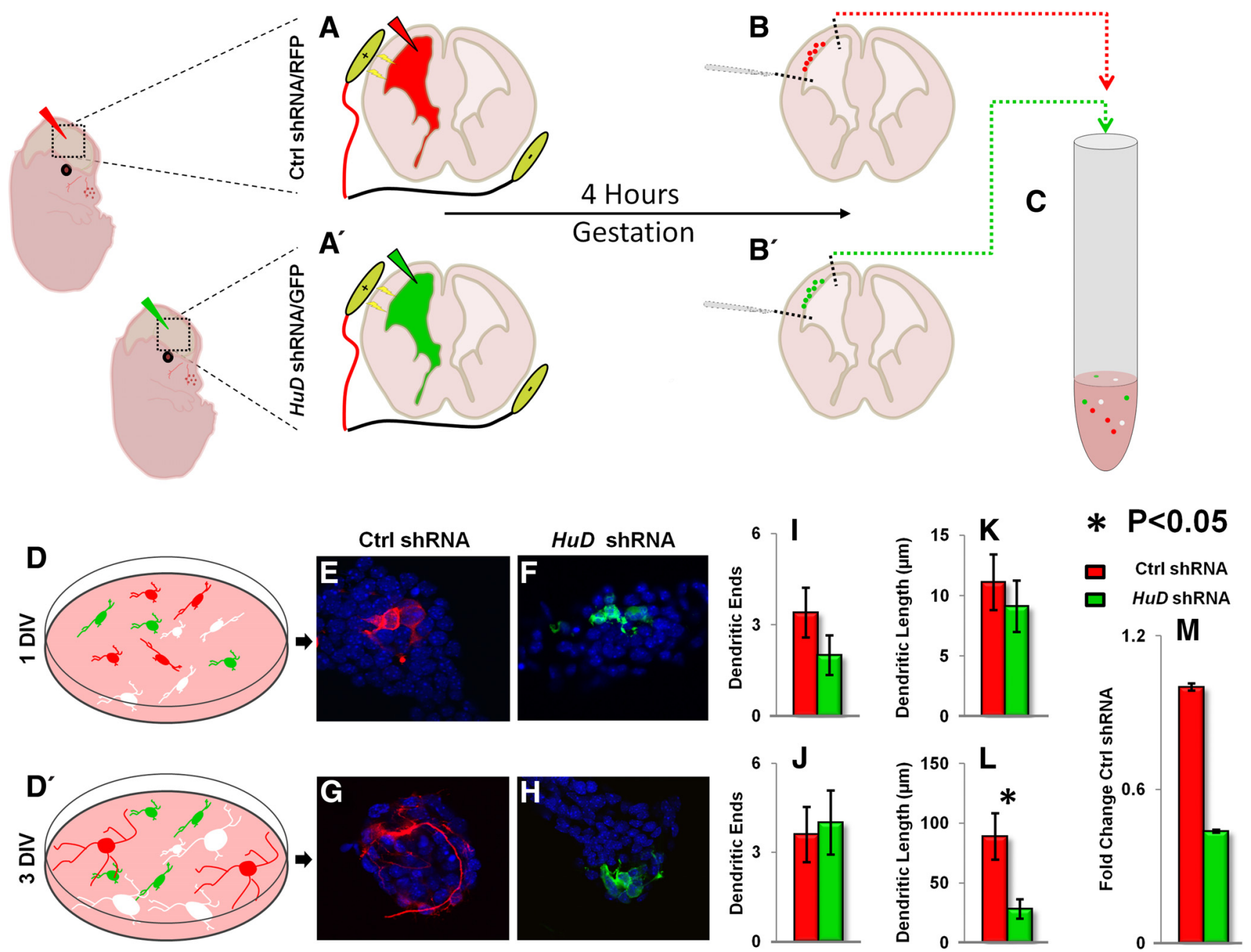

Figure 6. HuD controls the earliest stages of dendrite outgrowth. $\boldsymbol{A}-\boldsymbol{B}^{\prime}$, Schematic of In utero electroporation and dissociation of Ctrl shRNA/RFP (top) and HuD shRNA/GFP in E13.5 developing neocortex. Developing neocortices were electroporated at E13.5 with either (trl shRNA (RFP) or HuD shRNA (GFP). After $4 \mathrm{~h}$, neocortices were dissociated and cultured. C, Schematic of dissociation of electroporated neocortices for primary cell culture. $\boldsymbol{D}, \boldsymbol{D}^{\prime}$, Schematic of cell cultures taken at 1 and $3 \mathrm{DIV}$ for analysis. $\boldsymbol{E}$, $\boldsymbol{F}$, Representative $60 \times$ confocal images of Ctrl and $H u D$ shRNA transfected neurons at 1 DIV, respectively. $G, H$, Representative $60 \times$ confocal images of Ctrl and HuD shRNA transfected neurons at 3 DIV, respectively. $I-L$, Quantification of neurite endings in 1 and 3 DIV cell cultures. $M$, qRT-PCR analysis of HuD shRNA efficiency in vitro. Gapdh was used as a normalization control.

pared with control (mean dendrites $\mathrm{Ctrl}=4 \pm 1$ vs $\mathrm{HuD}$ shRNA $=4 \pm 1$, mean dendritic length Ctrl $=88.92 \pm 19.26$ vs HuD shRNA $=28.25 \pm 8.17 \mu \mathrm{m} p=0.016$, Fig. $6 F, H, J, L)$. Therefore, silencing of $\mathrm{HuD}$ at E13.5 reduced neurite outgrowth significantly $3 \mathrm{~d}$ after transfection. These findings support that $\mathrm{HuD}$ is critically involved in the earliest stages of dendrite outgrowth in the neocortex.

\section{$\mathrm{HuD} \mathrm{KO}$ mice are less active than WT}

To determine the effect of possible specification and circuitry deficits on the behavior of $H u D \mathrm{KO}$ mice, we used a novel device that generates a broad, spectral analysis of $H u D$ WT and KO littermates. The behavioral spectrometer reads photobeam breaks and vibrations of mice and extrapolates a multitude of behaviors. Figure 7 shows the effect of the KO manipulation on unconditioned behavior emitted by the mice in an open field. In general, $\mathrm{KO}$ mice significantly apportioned more of their time in low-energy-expending activities (stationary) and less in the highenergy activity of locomotion ( $p=0.012)$. In addition, within the four categories of behavior (stationary, orienting, rearing, and moving) the KO mice engaged significantly more $(p<0.05)$ in relatively less energetic actions such as "still," "sniff," "clean limb," and "shuffle" and significantly less $(p<0.05)$ time in energetic actions such as walking, running, and trying to climb the walls (i.e., "rear climb"). Typically, still behavior such as remaining prone or freezing indicate an anxiety response, suggesting that $H u D$ KO mice may have a greater propensity to anxiety-induced behaviors (Crawley, 1999; Lau et al., 2008).

$H u D$ KO mice display abnormalities water maze and elevated plus maze

Previous research has demonstrated motor deficits in $\mathrm{HuD} \mathrm{KO}$ mice; however, cognitive deficits have not been assessed (Akamatsu et al., 2005). To determine whether the deficiencies in hippocampal differentiation shown in Figure 4 affected the function of this circuit, we performed a behavioral analysis associated with this circuit, the Morris water maze. Previous work has demonstrated that $\mathrm{HuD}$ is upregulated in the hippocampus after the Morris water maze challenge (Pascale et al., 2004). In this task, mice swim toward a platform in an opaque bath and use visual cues surrounding a circular tub to orient themselves within the opaque bath to find a platform hidden below the water's surface. First, we tested the ability of WT and KO mice to find and swim toward a visible platform (Fig. $8 A$ ). By the third of five trials, $H u D$ 


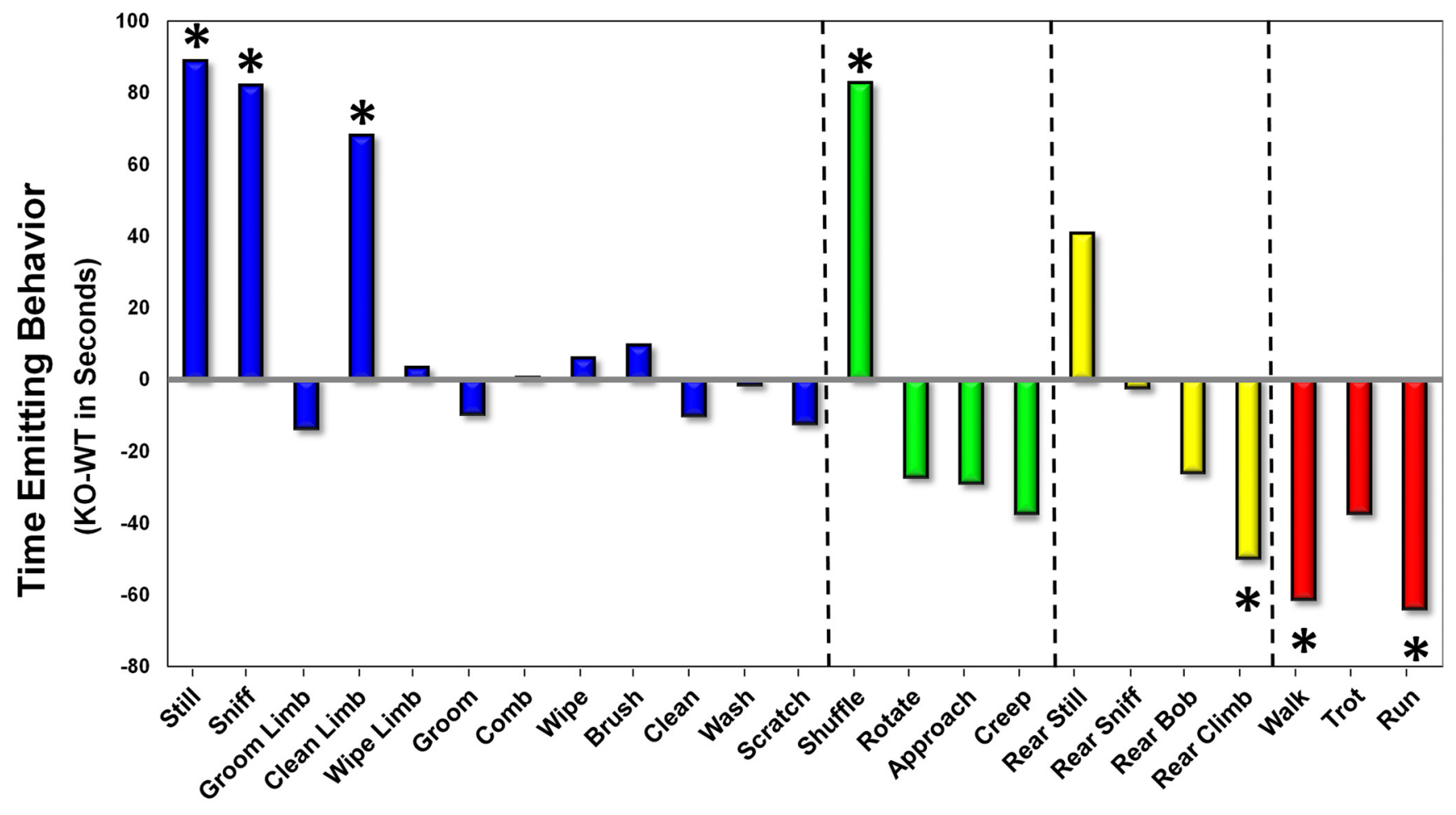

(Behaviors in order of increasing energy)

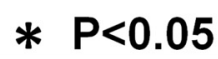

Figure 7. Spectral analysis of HuD KO shows reduced overall activity and increased stereotypic behaviors. Spectral analysis of total time spent performing each behavior where HuD KO mean-WT mean for each. Analysis was subdivided into four main categories; stationary, orienting, rearing, and moving.

KO mice swam to and mounted the platform as quickly as WT and there was no significant difference between the genotypes. Subsequently, mice were challenged to find the platform when it was submerged (hidden trial). Here, we found that $\mathrm{HuD} \mathrm{KO}$ mice took significantly longer to locate and mount the platform, especially in days 3 and 4 of this trial (WT means $=13.6,10.8,6.8$, and $5 \mathrm{~s}$ for trial days $1-4$, respectively, vs $\mathrm{KO}$ means $=17.1,12.8,13.2$, and $9.4 \mathrm{~s}, p=0.02,0.42,0.02$, and 0.03 for each trial, respectively; Fig. $8 B$ ). These data indicate that $H u D \mathrm{KO}$ mice have difficulty learning how to orient themselves in the water maze environment, particularly because they performed more poorly in the later trials.

Hippocampal and neocortical circuits are also part of the limbic system and are involved in anxiety (Packard, 2009). Therefore, we assessed the levels of anxiety in the $\mathrm{HuD} \mathrm{KO}$ mice by using the elevated plus maze. This maze contains an open arm (no walls) that mice avoid (Holt et al., 1988). Therefore, WT mice often spend most of the time in the closed portion of the maze. Compared with WT littermates, however, $H u D \mathrm{KO}$ mice spent a greater amount of the trial time in the open $\operatorname{arm}($ mean $\mathrm{WT}=59$ vs $\mathrm{KO}=118.5 \mathrm{~s}, p=0.011$; Fig. $8 C$ ), as well as a greater proportion of the trial in the open $\operatorname{arm}($ mean $\mathrm{WT}=11.7 \%$ vs $\mathrm{KO}=27.3 \%, p=0.041$; Fig. $8 D)$. These data indicate an aberrant response to anxiety-producing environments after $\mathrm{HuD}$ depletion or an inability to perceive the open arm as a threatening environment.

\section{$\mathrm{HuD}$ loss of function predisposes mice to} auditory-induced seizure

$\mathrm{Hu}$ proteins have been previously implicated in governing total cortical glutamate levels and neuronal excitability by mediating the expression of Glutaminase (Gls) in the cortex (Ince-Dunn et al., 2012). Further, our previous findings demonstrate that $\mathrm{HuD}$ controls aspects of circuit formation in the neocortex and hippocampus, two areas heavily implicated in the generation of seizures. Therefore, we assessed whether $\mathrm{HuD} \mathrm{KO}$ mice were more susceptible to auditory-induced seizures than WT littermates. To this end, we presented a metallic, auditory stimulus to $\mathrm{KO}$ animals and their WT littermates for 30 s (Halladay et al., 2006). Remarkably, $62.5 \%$ of $\mathrm{KO}$ animals responded with full-body convulsion, and $37.5 \%$ of those tested died subsequently (Fig. 9). In contrast, no WT animals experienced convulsion during this stimulus. These findings indicate that loss of $\mathrm{HuD}$ disrupts neuronal excitability in vivo.

\section{Discussion}

Upon initiating our study, we surmised that constitutive loss of $\mathrm{HuD}$ function would affect cortical circuit form and function in adult mice and that this would read out as cognitive and behavioral deficits. Our findings support this theory and demonstrate that $\mathrm{HuD}$ determines the molecular identity of a subpopulation of deep layer projection neurons of the adult neocortex. Further, we have demonstrated that $\mathrm{HuD}$ is involved in the dendritic arborization of a subset of lower layer neocortical projection neurons, as well as those in the CA3 region of the hippocampus. These findings are in agreement with studies performed in vitro strongly implicating HuD in dendritogenesis processes (Dobashi et al., 1998; Mobarak et al., 2000; Smith et al., 2004; Bolognani et al., 2007; Tanner et al., 2008; Perrone-Bizzozero et al., 2011). However, we also found that $\mathrm{HuD}$ is required for the appropriate dendrite overgrowth/expansion phase in neocortical layers $\mathrm{V}$ and VI at P28 because, by P90, WT length decreased to KO levels. We 


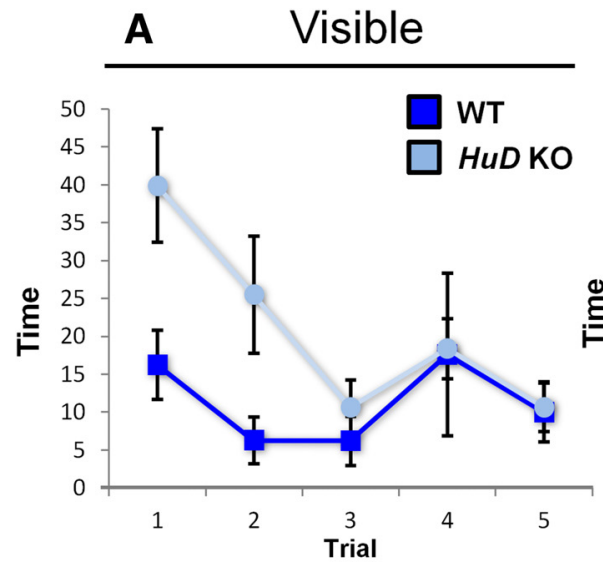

B Hidden
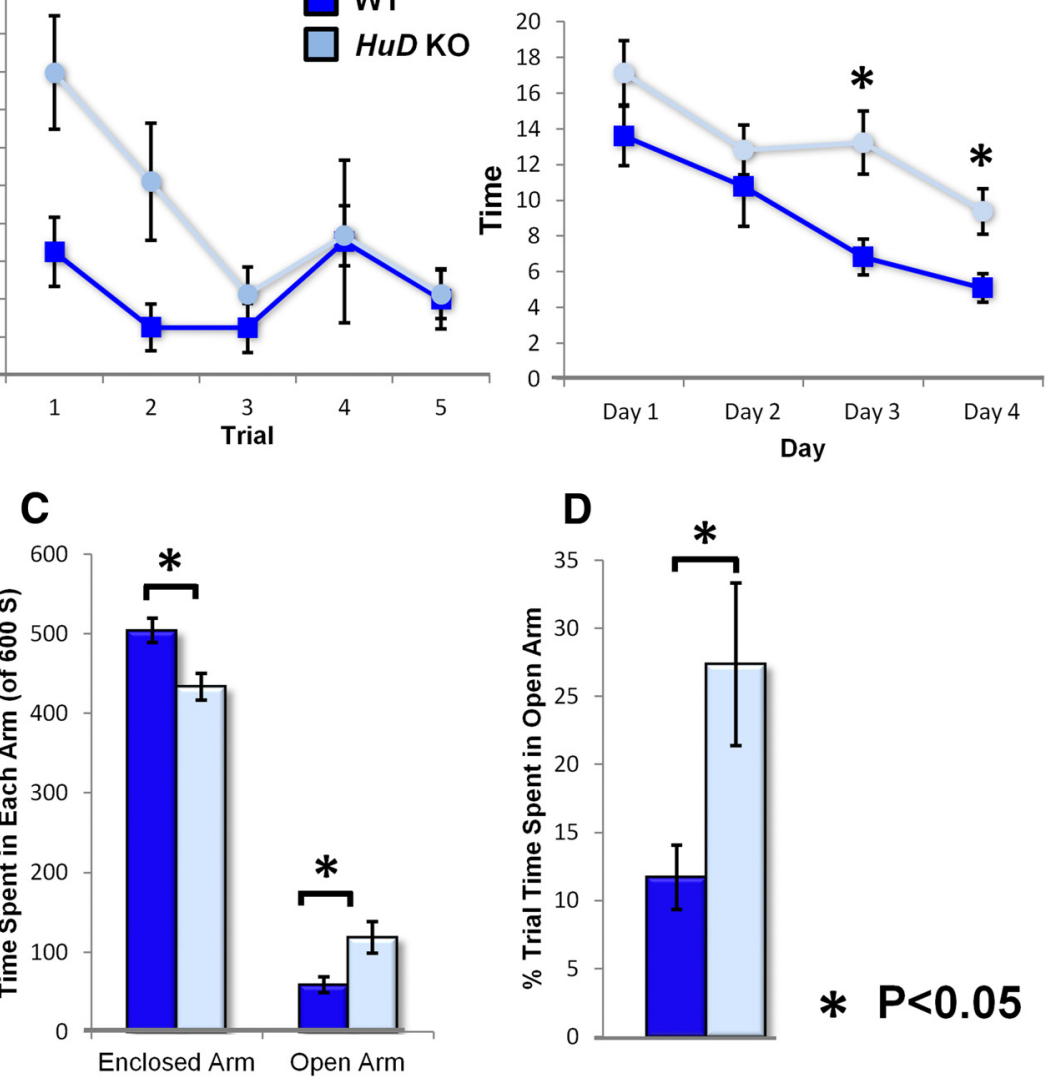

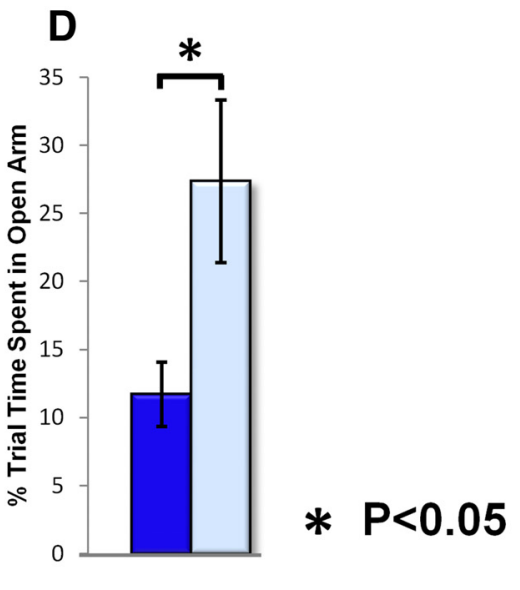

Figure 8. HuD KO mice perform poorly in Morris water maze and spend more time in the open arms of the elevated plus maze. $\boldsymbol{A}$, Average latency to find a visible platform by genotype in five trials of the Morris water maze. $\boldsymbol{B}$, Average latency to find a hidden platform by genotype in four consecutive days of testing, five trials per day. $C$, Average total time spent in the enclosed and open arms of the elevated plus maze by genotype. D, Proportion of total time spent in the open arms of the elevated plus maze by genotype. found that these molecular and neuroanatomical changes are accompanied by learning deficits in the Morris water maze test, a hippocampus-dependent task. We also noted that $H u D \mathrm{KO}$ mice are less anxious based on our findings in the behavioral spectrometer and elevated plus maze experiments. These results demonstrate a possible global role for $\mathrm{HuD}$ in the specification of neuron identity and circuit formation of the CNS, starting from stem cells (Akamatsu et al., 2005).

The study of glutamatergic neuronal subtypes in the neocortex is a field of intense interest given that projection neurons are functionally distinct and underlie a multitude of complex neocortical functions (Molyneaux et al., 2007; Leone et al., 2008; Kwan et al., 2012; DeBoer et al., 2013). As these studies progress, new molecular markers with increasing and overlapping specificity are desired to delineate the array of neocortical projection neuron subtypes. Our findings indicate that $\mathrm{HuD}$ is expressed in a subset of Tle $4^{+}$lower layer neocortical projection neurons. However, we found that $\mathrm{HuD}$ expression is more restricted to deeper layers than Tle4 and that colocalization between these two markers is only $60 \pm 10.5 \%$ (Fig. 1). Therefore, HuD-GFP could be particularly useful as a new molecular marker of a subpopulation deep layer cortical neurons in the adult neocortex. This pattern of expression is consistent with previous studies showing that $H u D$ mRNA is expressed more deeply in the cortex than

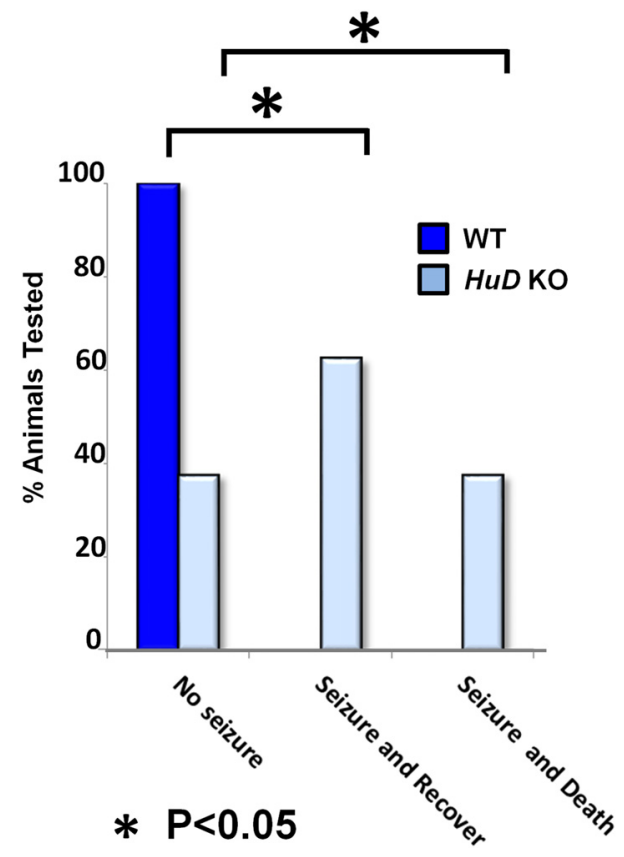

Figure 9. HuD KO mice are more susceptible to auditory induced seizure than WT. Shown is a quantification of the proportion of mice that did not experience seizure, experienced a seizure and subsequently recovered, or experienced seizure and immediately died.
$H u C$ (Okano and Darnell, 1997; Magdaleno et al., 2006). It is possible that there are differences between our $\mathrm{HuD}$ reporter expression and $\mathrm{HuD}$ protein expression. However, this is unlikely given that previous findings at the mRNA level show similar expression. HuD is more ubiquitously expressed throughout the cortex in development and expression becomes more limited and regionally specific in the adult. Our findings and previous data demonstrate a decrease in $\mathrm{HuD}$ expression from $\mathrm{P} 7$ to the adult stage (Bolognani et al., 2007). Therefore, HuD may have active roles in the establishment and maturation of cortical circuits.

Interestingly, our analysis showed specificity in $\mathrm{HuD}$ effects on cortical neurons. We found that only the dendritic arborization of a subset of lower neocortical layers was affected by $\mathrm{HuD}$ loss of function. Newly formed dendrites will expand and overgrow due to growth factors, which will later be fine tuned by activity to decrease the length (Metzger, 2010). Our data demonstrate that lower neocortical dendrites fail to efficiently extend dendrites at P28 in the KO compared with similar aged WT littermates. When analyzed again at P90, HuD KO dendrites were of similar length to P28 KO, whereas WT dendrites of P90 animals retracted significantly. Early overgrowth followed by a subsequent retraction period is a known phenomenon in neocortex and may be a critical phenomenon for the formation of balanced, mature cortical circuitry (Judas et al., 2003; Metzger, 2010; Petanjek et al., 2011), which may be evolutionary also adapted (Petanjek et al., 2008). Our data also demonstrate pervasive deficits in 
dendritic complexity of projection neurons in both lower neocortical layers and the hippocampal CA3 subregion of $H u D$ KOs. In this way, $\mathrm{HuD}$ may have a dual effect on normal process of circuitry establishment and circuit maintenance in the neocortex and hippocampus. To our knowledge, $\mathrm{HuD}$ is the first RBP to be described as having a specific role in initial dendritic overgrowth/ expansion in the developing neocortex.

Previous work has demonstrated that the molecular players in the differentiation of upper and lower neocortical layers are different (Chen et al., 2005; Chen et al., 2008; Gyorgy et al., 2008; Cubelos et al., 2010; Srinivasan et al., 2012). Although the mechanism of $\mathrm{HuD}$ and many of its targets have been partially elucidated, HuD binds promiscuously and likely mediates the metabolism of a multitude of transcripts that coordinately carry out neuronal maturation in the cortex (Ince-Dunn et al., 2012). $\mathrm{HuD}$ is also known to be involved in several stages of mRNA metabolism: nuclear transport, subcellular transport, stabilization, and translation (Kasashima et al., 1999; Bolognani et al., 2007; Fukao et al., 2009; Fallini et al., 2011). Further, given our data showing that $\mathrm{HuD}$ is involved in the process of neuronal specification and arborization, it is likely that the targets of $\mathrm{HuD}$ may be differential throughout cortical neurogenesis, postmitotic specification, and dendritogenesis.

The lower layer neocortical neurons in which we noted $\mathrm{HuD}$ expression project subcortically, primarily to the thalamus, brainstem, and spinal cord (Chen et al., 2005; Kriegstein and Alvarez-Buylla, 2009; McKenna et al., 2011; DeBoer et al., 2013). The corticospinal and corticothalamic neurons are found in this region and control complex sensorimotor behavior. Our finding that $\mathrm{HuD}$ loss of function inhibits the specification and differentiation of these lower layers suggest that disruption in motor circuits guides fine motor movements in rodents. These findings are consistent with previous reports showing that $\mathrm{HuD} \mathrm{KO}$ mice are less able to perform well on the rotorod challenge (Akamatsu et al., 2005).

One of our central findings is that $\mathrm{HuD} \mathrm{KO}$ mice are more susceptible to seizure induced by an auditory stimulus than WT littermates. This novel finding also follows previous research that $\mathrm{Hu}$ proteins govern neuronal excitability given that hyperexcitibility of cortical circuitry is a hallmark of epilepsy (Ince-Dunn et al., 2012). These findings implicated $\mathrm{HuC} / \mathrm{D}$ in the translation of Gls, which ultimately controls cortical glutamate levels. Further, these studies demonstrated that the $\mathrm{HuC}$ knock-out mouse has baseline abnormalities in EEG with the appearance of seizure without convulsion. Our findings suggest that the loss of $\mathrm{HuD}$ function predisposes mice to behavioral convulsion in the presence of an auditory stimulus and that a subset of glutamatergic neurons' morphology is disrupted. In concert, these findings suggest that RNA metabolism through $\mathrm{Hu}$ family proteins may be critical for appropriate cortical circuit function and warrant subsequent investigation as epileptic risk factors in the clinical setting. At the preclinical level, the mechanism of $\mathrm{Hu}$ proteins' involvement in convulsion must be further investigated. For example, subdissections of the HuD-GFP mouse in the WT and $H u D \mathrm{KO}$ background coupled to flow cytometric sorting and ribosomal footprinting or HITS-CLIP may elucidate the metabolism of HuD-regulated transcripts in a cell-specific fashion. These data may help investigators to identify messages implicated in seizure that are governed by HuD. Further, the focal region of $\mathrm{Hu}$ loss of function seizures has not been investigated and field potential recordings from the available KOs may be instructive in this regard. In addition, we analyzed KOs that have $\mathrm{HuD}$ depleted very early in development, suggesting that early events may un- derlie convulsions in adults, which is in agreement with previous findings (Wang et al., 2011).

Clinical studies have associated single nucleotide polymorphisms in HuD with Parkinson's disease age of onset; however, there is no established link with the epileptic movement disorders (Noureddine et al., 2005; Haugarvoll et al., 2007; DeStefano et al., 2008). Perhaps subsequent work will scrutinize data from these studies for the presence of epilepsy in populations with $\mathrm{HuD}$ mutations. Furthermore, cognitive deficits are a common comorbidity of epilepsy (Perrine and Kiolbasa, 1999), which is in agreement with our Morris water maze findings. The results of our study implicate $\mathrm{HuD}$ in the generation and differentiation of cortical brain regions and their lifelong function. In concert with previous work, these findings implicate $\mathrm{HuD}$ as a uniquely brainexpressed posttranscriptional regulator of mRNA metabolism that is involved in many key steps of cortical generation, from governance of early stem cell cycles to the excitability and function of cortical circuits.

\section{References}

Abdelmohsen K, Hutchison ER, Lee EK, Kuwano Y, Kim MM, Masuda K, Srikantan S, Subaran SS, Marasa BS, Mattson MP, Gorospe M (2010) miR-375 inhibits differentiation of neurites by lowering HuD levels. Mol Cell Biol 30:4197-4210. CrossRef Medline

Akamatsu W, Fujihara H, Mitsuhashi T, Yano M, Shibata S, Hayakawa Y, Okano HJ, Sakakibara S, Takano H, Takano T, Takahashi T, Noda T, Okano H (2005) The RNA-binding protein HuD regulates neuronal cell identity and maturation. Proc Natl Acad Sci U S A 102:4625-4630. CrossRef Medline

Anderson GR, Galfin T, Xu W, Aoto J, Malenka RC, Südhof TC (2012) Candidate autism gene screen identifies critical role for cell-adhesion molecule CASPR2 in dendritic arborization and spine development. Proc Natl Acad Sci U S A 109:18120-18125. CrossRef Medline

Anderson KD, Morin MA, Beckel-Mitchener A, Mobarak CD, Neve RL, Furneaux HM, Burry R, Perrone-Bizzozero NI (2000) Overexpression of $\mathrm{HuD}$, but not of its truncated form $\mathrm{HuD} \mathrm{I}^{+} \mathrm{II}$, promotes GAP-43 gene expression and neurite outgrowth in PC12 cells in the absence of nerve growth factor. J Neurochem 75:1103-1114. CrossRef Medline

Anderson KD, Sengupta J, Morin M, Neve RL, Valenzuela CF, PerroneBizzozero NI (2001) Overexpression of HuD accelerates neurite outgrowth and increases GAP-43 mRNA expression in cortical neurons and retinoic acid-induced embryonic stem cells in vitro. Exp Neurol 168:250 258. CrossRef Medline

Aranda-Abreu GE, Behar L, Chung S, Furneaux H, Ginzburg I (1999) Embryonic lethal abnormal vision-like RNA-binding proteins regulate neurite outgrowth and tau expression in PC12 cells. J Neurosci 19:6907-6917. Medline

Arlotta P, Molyneaux BJ, Chen J, Inoue J, Kominami R, Macklis JD (2005) Neuronal subtype-specific genes that control corticospinal motor neuron development in vivo. Neuron 45:207-221. CrossRef Medline

Arnsten AF (2013) The neurobiology of thought: the groundbreaking discoveries of Patricia Goldman-Rakic 1937-2003. Cereb Cortex 23:22692281. CrossRef Medline

Bithell A, Finch SE, Hornby MF, Williams BP (2008) Fibroblast growth factor 2 maintains the neurogenic capacity of embryonic neural progenitor cells in vitro but changes their neuronal subtype specification. Stem Cells 26:1565-1574. CrossRef Medline

Bolognani F, Tanner DC, Nixon S, Okano HJ, Okano H, Perrone-Bizzozero NI (2007) Coordinated expression of HuD and GAP-43 in hippocampal dentate granule cells during developmental and adult plasticity. Neurochem Res 32:2142-2151. CrossRef Medline

Bystron I, Blakemore C, Rakic P (2008) Development of the human cerebral cortex: Boulder Committee revisited. Nat Rev Neurosci 9:110-122. CrossRef Medline

Chen B, Wang SS, Hattox AM, Rayburn H, Nelson SB, McConnell SK (2008) The Fezf2-Ctip2 genetic pathway regulates the fate choice of subcortical projection neurons in the developing cerebral cortex. Proc Natl Acad Sci U S A 105:11382-11387. CrossRef Medline

Chen JG, Rasin MR, Kwan KY, Sestan N (2005) Zfp312 is required for subcortical axonal projections and dendritic morphology of deep-layer pyra- 
midal neurons of the cerebral cortex. Proc Natl Acad Sci U S A 102: 17792-17797. CrossRef Medline

Chung S, Eckrich M, Perrone-Bizzozero N, Kohn DT, Furneaux H (1997) The Elav-like proteins bind to a conserved regulatory element in the 3'-untranslated region of GAP-43 mRNA. J Biol Chem 272:6593-6598. CrossRef Medline

Clement JP, Aceti M, Creson TK, Ozkan ED, Shi Y, Reish NJ, Almonte AG, Miller BH, Wiltgen BJ, Miller CA, Xu X, Rumbaugh G (2012) Pathogenic SYNGAP1 mutations impair cognitive development by disrupting maturation of dendritic spine synapses. Cell 151:709-723. CrossRef Medline

Crawley JN (1999) Behavioral phenotyping of transgenic and knockout mice: experimental design and evaluation of general health, sensory functions, motor abilities, and specific behavioral tests. Brain Res 835:18-26. CrossRef Medline

Cubelos B, Sebastián-Serrano A, Beccari L, Calcagnotto ME, Cisneros E, Kim S, Dopazo A, Alvarez-Dolado M, Redondo JM, Bovolenta P, Walsh CA, Nieto M (2010) Cux1 and Cux2 regulate dendritic branching, spine morphology, and synapses of the upper layer neurons of the cortex. Neuron 66:523-535. CrossRef Medline

Darsalia V, Kallur T, Kokaia Z (2007) Survival, migration and neuronal differentiation of human fetal striatal and cortical neural stem cells grafted in stroke-damaged rat striatum. Eur J Neurosci 26:605-614. CrossRef Medline

DeBoer EM, Rasin MR (2013) Nucleoside analog labeling of neural stem cells and their progeny. Methods Mol Biol 1018:21-37. CrossRef Medline

Deboer EM, Kraushar ML, Hart RP, Rasin MR (2013) Post-transcriptional regulatory elements and spatiotemporal specification of neocortical stem cells and projection neurons. Neuroscience 248C:499-528. CrossRef Medline

DeFelipe J, López-Cruz PL, Benavides-Piccione R, Bielza C, Larrañaga P, Anderson S, Burkhalter A, Cauli B, Fairén A, Feldmeyer D, Fishell G, Fitzpatrick D, Freund TF, González-Burgos G, Hestrin S, Hill S, Hof PR, Huang J, Jones EG, Kawaguchi Y, et al. (2013) New insights into the classification and nomenclature of cortical GABAergic interneurons. Nat Rev Neurosci 14:202-216. CrossRef Medline

DeStefano AL, Latourelle J, Lew MF, Suchowersky O, Klein C, Golbe LI, Mark MH, Growdon JH, Wooten GF, Watts R, Guttman M, Racette BA, Perlmutter JS, Marlor L, Shill HA, Singer C, Goldwurm S, Pezzoli G, SaintHilaire MH, Hendricks AE, et al. (2008) Replication of association between ELAVL4 and Parkinson disease: the GenePD study. Hum Genet 124:95-99. CrossRef Medline

Dobashi Y, Shoji M, Wakata Y, Kameya T (1998) Expression of HuD protein is essential for initial phase of neuronal differentiation in rat pheochromocytoma PC12 cells. Biochem Biophys Res Comm 244:226-229. CrossRef Medline

Donnelly CJ, Park M, Spillane M, Yoo S, Pacheco A, Gomes C, Vuppalanchi D, McDonald M, Kim HK, Merianda TT, Gallo G, Twiss JL (2013) Axonally Synthesized $\beta$-actin and GAP-43 proteins support distinct modes of axonal growth. J Neurosci 33:3311-3322. CrossRef Medline

Fallini C, Zhang H, Su Y, Silani V, Singer RH, Rossoll W, Bassell GJ (2011) The survival of motor neuron (SMN) protein interacts with the mRNAbinding protein $\mathrm{HuD}$ and regulates localization of poly(A) mRNA in primary motor neuron axons. J Neurosci 31:3914-3925. CrossRef Medline

Fukao A, Sasano Y, Imataka H, Inoue K, Sakamoto H, Sonenberg N, Thoma C, Fujiwara T (2009) The ELAV protein HuD stimulates cap-dependent translation in a poly(A)- and eIF4A-dependent manner. Mol Cell 36: 1007-1017. CrossRef Medline

Gibb R, Kolb B (2005) Neonatal handling alters brain organization but does not influence recovery from perinatal cortical injury. Behav Neurosci 119:1375-1383. CrossRef Medline

Gong S, Zheng C, Doughty ML, Losos K, Didkovsky N, Schambra UB, Nowak NJ, Joyner A, Leblanc G, Hatten ME, Heintz N (2003) A gene expression atlas of the central nervous system based on bacterial artificial chromosomes. Nature 425:917-925. CrossRef Medline

Guillemot F (2005) Cellular and molecular control of neurogenesis in the mammalian telencephalon. Curr Opin Cell Biol 17:639-647. CrossRef Medline

Gyorgy AB, Szemes M, de Juan Romero C, Tarabykin V, Agoston DV (2008) SATB2 interacts with chromatin-remodeling molecules in differentiating cortical neurons. Eur J Neurosci 27:865-873. CrossRef Medline
Halladay AK, Wagner GC, Sekowski A, Rothman RB, Baumann MH, Fisher H (2006) Alterations in alcohol consumption, withdrawal seizures, and monoamine transmission in rats treated with phentermine and 5-hydroxy-L-tryptophan. Synapse 59:277-289. CrossRef Medline

Haugarvoll K, Toft M, Ross OA, Stone JT, Heckman MG, White LR, Lynch T, Gibson JM, Wszolek ZK, Uitti RJ, Aasly JO, Farrer MJ (2007) ELAVL4, PARK10, and the Celts. Mov Disord 22:585-587. CrossRef Medline

Holt CE, Bertsch TW, Ellis HM, Harris WA (1988) Cellular determination in the Xenopus retina is independent of lineage and birth date. Neuron 1:15-26. CrossRef Medline

Ince-Dunn G, Okano HJ, Jensen KB, Park WY, Zhong R, Ule J, Mele A, Fak JJ, Yang C, Zhang C, Yoo J, Herre M, Okano H, Noebels JL, Darnell RB (2012) Neuronal Elav-like (Hu) proteins regulate RNA splicing and abundance to control glutamate levels and neuronal excitability. Neuron 75:1067-1080. CrossRef Medline

Judas M, Rasin MR, Kruslin B, Kostović K, Jukić D, Petanjek Z, Kostović I (2003) Dendritic overgrowth and alterations in laminar phenotypes of neocortical neurons in the newborn with semilobar holoprosencephaly. Brain Dev 25:32-39. CrossRef Medline

Kasashima K, Terashima K, Yamamoto K, Sakashita E, Sakamoto H (1999) Cytoplasmic localization is required for the mammalian ELAV-like protein $\mathrm{HuD}$ to induce neuronal differentiation. Genes Cells 4:667-683. CrossRef Medline

Keene JD (2007) RNA regulons: coordination of post-transcriptional events. Nat Rev Genet 8:533-543. CrossRef Medline

Kitaura H, Hiraishi T, Murakami H, Masuda H, Fukuda M, Oishi M, Ryufuku M, Fu YJ, Takahashi H, Kameyama S, Fujii Y, Shibuki K, Kakita A (2011) Spatiotemporal dynamics of epileptiform propagations: imaging of human brain slices. Neuroimage 58:50-59. CrossRef Medline

Kriegstein A, Alvarez-Buylla A (2009) The glial nature of embryonic and adult neural stem cells. Annu Rev Neurosci 32:149-184. CrossRef Medline

Kwan KY, Sestan N, Anton ES (2012) Transcriptional co-regulation of neuronal migration and laminar identity in the neocortex. Development 139: 1535-1546. CrossRef Medline

Lau AA, Crawley AC, Hopwood JJ, Hemsley KM (2008) Open field locomotor activity and anxiety-related behaviors in mucopolysaccharidosis type IIIA mice. Behav Brain Res 191:130-136. CrossRef Medline

Lee A, Maldonado M, Baybis M, Walsh CA, Scheithauer B, Yeung R, Parent J, Weiner HL, Crino PB (2003) Markers of cellular proliferation are expressed in cortical tubers. Ann Neurol 53:668-673. CrossRef Medline

Leone DP, Srinivasan K, Chen B, Alcamo E, McConnell SK (2008) The determination of projection neuron identity in the developing cerebral cortex. Curr Opin Neurobiol 18:28-35. CrossRef Medline

Lui JH, Hansen DV, Kriegstein AR (2011) Development and evolution of the human neocortex. Cell 146:18-36. CrossRef Medline

Magdaleno S, Jensen P, Brumwell CL, Seal A, Lehman K, Asbury A, Cheung T, Cornelius T, Batten DM, Eden C, Norland SM, Rice DS, Dosooye N, Shakya S, Mehta P, Curran T (2006) BGEM: an in situ hybridization database of gene expression in the embryonic and adult mouse nervous system. PLoS Biol 4:e86. CrossRef Medline

McKenna WL, Betancourt J, Larkin KA, Abrams B, Guo C, Rubenstein JL, Chen B (2011) Tbr1 and Fezf2 regulate alternate corticofugal neuronal identities during neocortical development. J Neurosci 31:549-564. CrossRef Medline

Melzer S, Michael M, Caputi A, Eliava M, Fuchs EC, Whittington MA, Monyer H (2012) Long-range-projecting GABAergic neurons modulate inhibition in hippocampus and entorhinal cortex. Science 335:15061510. CrossRef Medline

Metzger F (2010) Molecular and cellular control of dendrite maturation during brain development. Curr Mol Pharmacol 3:1-11. CrossRef Medline

Mobarak CD, Anderson KD, Morin M, Beckel-Mitchener A, Rogers SL, Furneaux H, King P, Perrone-Bizzozero NI (2000) The RNA-binding protein $\mathrm{HuD}$ is required for GAP-43 mRNA stability, GAP-43 gene expression, and PKC-dependent neurite outgrowth in PC12 cells. Mol Biol Cell 11:3191-3203. CrossRef Medline

Molyneaux BJ, Arlotta P, Menezes JR, Macklis JD (2007) Neuronal subtype specification in the cerebral cortex. Nat Rev Neurosci 8:427-437. CrossRef Medline

Noureddine MA, Qin XJ, Oliveira SA, Skelly TJ, van der Walt J, Hauser MA, Pericak-Vance MA, Vance JM, Li YJ (2005) Association between the 
neuron-specific RNA-binding protein ELAVL4 and Parkinson disease. Hum Genet 117:27-33. CrossRef Medline

Okano HJ, Darnell RB (1997) A hierarchy of Hu RNA binding proteins in developing and adult neurons. J Neurosci 17:3024-3037. Medline

Packard MG (2009) Anxiety, cognition, and habit: a multiple memory systems perspective. Brain Res 1293:121-128. CrossRef Medline

Pascale A, Gusev PA, Amadio M, Dottorini T, Govoni S, Alkon DL, Quattrone A (2004) Increase of the RNA-binding protein $\mathrm{HuD}$ and posttranscriptional up-regulation of the GAP-43 gene during spatial memory. Proc Natl Acad Sci U S A 101:1217-1222. CrossRef Medline

Perrine K, Kiolbasa T (1999) Cognitive deficits in epilepsy and contribution to psychopathology. Neurology 53:S39-48. Medline

Perrone-Bizzozero NI, Tanner DC, Mounce J, Bolognani F (2011a) Increased expression of axogenesis-related genes and mossy fibre length in dentate granule cells from adult $\mathrm{HuD}$ overexpressor mice. ASN Neuro 3:259-270. CrossRef Medline

Petanjek Z, Judas M, Kostović I, Uylings HB (2008) Lifespan alterations of basal dendritic trees of pyramidal neurons in the human prefrontal cortex: a layer-specific pattern. Cereb Cortex 18:915-929. CrossRef Medline

Petanjek Z, Judaš M, Šimic G, Rasin MR, Uylings HB, Rakic P, Kostovic I (2011) Extraordinary neoteny of synaptic spines in the human prefrontal cortex. Proc Natl Acad Sci U S A 108:13281-13286. CrossRef Medline

Pitchers KK, Balfour ME, Lehman MN, Richtand NM, Yu L, Coolen LM (2010) Neuroplasticity in the mesolimbic system induced by natural reward and subsequent reward abstinence. Biol Psychiatry 67:872-879. CrossRef Medline

Rasin MR, Darmopil S, Petanjek Z, Tomić-Mahecić T, Mohammed AH, Bogdanović N (2011) Effect of environmental enrichment on morphology of deep layer III and layer V pyramidal cells of occipital cortex in oldest-old rat-a quantitative Golgi cox study. Coll Antropol 35:253-258. Medline

Rasin MR, Gazula VR, Breunig JJ, Kwan KY, Johnson MB, Liu-Chen S, Li HS, Jan LY, Jan YN, Rakic P, Sestan N (2007) Numb and Numbl are required for maintenance of cadherin-based adhesion and polarity of neural progenitors. Nat Neurosci 10:819-827. CrossRef Medline

Sestan N, Artavanis-Tsakonas S, Rakic P (1999) Contact-dependent inhibition of cortical neurite growth mediated by notch signaling. Science 286 : 741-746. CrossRef Medline

Shoemaker LD, Arlotta P (2010) Untangling the cortex: Advances in understanding specification and differentiation of corticospinal motor neurons. BioEssays 32:197-206. CrossRef Medline

Smith CL, Afroz R, Bassell GJ, Furneaux HM, Perrone-Bizzozero NI, Burry RW (2004) GAP-43 mRNA in growth cones is associated with HuD and ribosomes. J Neurobiol 61:222-235. CrossRef Medline

Srinivasan K, Leone DP, Bateson RK, Dobreva G, Kohwi Y, KohwiShigematsu T, Grosschedl R, McConnell SK (2012) A network of genetic repression and derepression specifies projection fates in the developing neocortex. Proc Natl Acad Sci U S A 109:19071-19078. CrossRef Medline

Szabo A, Dalmau J, Manley G, Rosenfeld M, Wong E, Henson J, Posner JB, Furneaux HM (1991) HuD, a paraneoplastic encephalomyelitis antigen, contains RNA-binding domains and is homologous to Elav and Sexlethal. Cell 67:325-333. CrossRef Medline

Tanner DC, Qiu S, Bolognani F, Partridge LD, Weeber EJ, Perrone-Bizzozero NI (2008) Alterations in mossy fiber physiology and GAP-43 expression and function in transgenic mice overexpressing HuD. Hippocampus 18: 814-823. CrossRef Medline

Wang Y, Yin X, Rosen G, Gabel L, Guadiana SM, Sarkisian MR, Galaburda AM, Loturco JJ (2011) Dcdc2 knockout mice display exacerbated developmental disruptions following knockdown of doublecortin. Neuroscience 190:398-408. CrossRef Medline

Zivraj KH, Tung YC, Piper M, Gumy L, Fawcett JW, Yeo GS, Holt CE (2010) Subcellular profiling reveals distinct and developmentally regulated repertoire of growth cone mRNAs. J Neurosci 30:15464-15478. CrossRef Medline 